\title{
Overview of major processes and mechanisms affecting the mercury cycle on different spatial and temporal scales
}

\author{
N. Pirrone ${ }^{1,2, a}$, I.M. Hedgecock ${ }^{2}$, S. Cinnirella ${ }^{2}$, and F. Sprovieri ${ }^{2}$ \\ 1 CNR-Institute of Atmospheric Pollution Research, Rome, Italy \\ 2 CNR-Institute of Atmospheric Pollution Research, Division of Rende, 87036 Rende, Italy
}

\begin{abstract}
Mercury emissions to the atmosphere and its transport, transformation and deposition to and re-emission from terrestrial and aquatic ecosystems on hemispherical and global scales has received increasing attention from both the scientific and the regulatory communities during the last twenty years. It is well known that the atmosphere is the major transport media through which mercury is redistributed on global scale once it is released from point and diffuse emission sources. A substantial amount of research has been carried out worldwide aiming to assess the relationships between emissions from natural vs. anthropogenic sources, inter-hemispherical atmospheric transport patterns, and atmospheric deposition to and re-emission from oceans, its bioaccumulation in fish, and evaluation of policy strategies to reduce the impact of mercury emissions on human health and ecosystems. This chapter provides a highlight of key aspects related to mercury contamination, including: a) major processes affecting the mercury cycle between the atmosphere and aquatic and terrestrial ecosystems, b) mercury emissions from natural and anthropogenic sources, c) spatial and temporal distributions and trends of mercury species over the northern and southern hemispheres, d) the chemical and physical processes affecting the transport and fate of atmospheric mercury, and e)major policy frameworks aiming to control the impact of mercury on human health and ecosystems.
\end{abstract}

\section{Introduction}

Mercury is ubiquitous in the atmosphere, it has ground level background concentrations which are almost constant over hemispheric scales; the southern hemisphere having a slightly lower concentration than the northern. Mercury is emitted into the atmosphere from a variety of anthropogenic and natural sources. Of the anthropogenic sources, among the most important are fossil fuel combustion, smelting, cement production and waste incineration, while the oceans are the largest natural source of $\mathrm{Hg}$ to the atmosphere, volcanism also makes an important contribution [1-6]. Most mercury emissions are of elemental $\mathrm{Hg}$ but anthropogenic emissions also include $\mathrm{Hg}$ in different chemical and physical forms. Mercury cycling between different environmental compartments depends on the dynamic of chemical and physical processes (i.e. oxidation and reduction, dry deposition, wet scavenging/depostion, re-emission and methylation,) which influence its transport and residence time in the global environment. Due to intensified anthropogenic emission of mercury into the atmosphere since the beginning of industrialization this global $\mathrm{Hg}$ pool has increased in the past 150 years, evidence suggests that the global atmospheric burden has increased by a factor of 3 to 5 for example. Recent measurements of free tropospheric air, from high altitude sites and from measurements made on board

\footnotetext{
a e-mail: pirrone@iia.cnr.it
}

This is an Open Access article distributed under the terms of the Creative Commons Attribution-Noncommercial License 3.0, which permits unrestricted use, distribution, and reproduction in any noncommercial medium, provided the original work is properly cited. 
aircrafts indicate that the elemental $\mathrm{Hg}$ concentration changes little up to the tropopause, although events in which higher than usual concentrations of oxidised $\mathrm{Hg}$ species are observed do occur [7-9]. In the stratosphere mercury has been identified associated with stratospheric aerosols [10], and almost total depletion of elemental $\mathrm{Hg}$ recorded [11]. Therefore, mercury is found in the boundary layer, in the free troposphere and stratosphere; and the transport and fate of mercury is determined by the different chemical, physical and meteorological environments presnt in these regions of the atmosphere and also by the exchange between them [9]. Evidence of long-term changes in the atmospheric mercury burden have been derived from chemical analysis of lake sediments, ice cores, peat deposits and firm air records [7,9,12-14]. These studies identify a peak in the atmospheric mercury concentration during the $70 \mathrm{~s}$ in the Northern Hemisphere. A growing number of these records from both hemispheres demonstrate approximately a threefold increase of mercury deposition since pre-industrial times [9]. In principle, an increase in the global atmospheric pool should also be reflected in the background concentration. However, since the first reliable measurement data were published just 30 years ago, it is extremely difficult to determine a global trend from the existing spatially and temporally inchoate air concentration data sets. For example, Asian mercury emissions are believed to have rapidly increased over the last decade [2,15], however, this is not reflected either in the long-term measurement of Total Gaseous Mercury (TGM) at Mace Head, Ireland covering the period between 1996 to 2006 $[16,17]$, nor in the precipitation data of the North American Mercury Deposition Network (MDN). Recognizing that TGM and the Hg flux to the earth's surface in dry and wet deposition are spatially heterogeneous, several initiatives have aimed to set up monitoring networks in order to compare trends between sites in the same region, between regions, and to determine the influence of local and regional emission sources. There is also interest in understanding the processes that contribute to $\mathrm{Hg}$ species concentration variability on a diurnal, weekly, seasonal, and annual basis. In 1995, Fitzgerald [18] argued for and defined the basic requirements of an Atmospheric Mercury Network (AMNet). This has partly been accomplished on a regional scale within the Canadian Atmospheric Mercury Network (CAMNet), which may be considered as seminal in this respect. Part of the CAMNet contributes also to the Arctic Monitoring and Assessment Program (AMAP) under the Ministry Council of Circum Polar Countries and where there are also contributions from the Scandinavian countries. Nevertheless, although the number of atmospheric $\mathrm{Hg}$ monitoring stations has increased [19], the database is sparse, especially in remote locations suitable for the assessment of the trend in background $\mathrm{Hg}$ concentrations. In Europe atmospheric mercury measurements have been performed since the early $80 \mathrm{~s}$ at selected northern European sites as part of the European Monitoring Evaluation Program (EMEP) of the UNECE-LRTAP convention. This network detected the decrease in atmospheric $\mathrm{Hg}$ concentrations and $\mathrm{Hg}$ in precipitation which occurred when Eastern European countries went into economic decline in the late 1980's leading to the closure of a significant number of industrial installations. Later, as part of three European Commission funded projects, (MAMCS, MOE and MERCYMS) a first attempt was made to establish an European wide measurement network. One of the major outcomes of these EU projects was that for the first time, simultaneous measurements of speciated mercury were performed at 10 measurement sites located across Europe during several two-week intensive campaigns at both ground-based and off-shore sites [20-24]. The results of these projects allowed, among other things, the preparation of the European Position Paper on Mercury [25] which provided the scientific background of the $4^{\text {th }}$ Daughter Air Quality Directive. One of the major findings of these projects was a better understanding of the role of Marine Boundary Layer (MBL) in the oxidation of elemental $\mathrm{Hg}$. Oxidized $\mathrm{Hg}$ compounds are more readily deposited to surface waters and terrestrial ecosystems than elemental $\mathrm{Hg}$ leading to a variation of the atmospheric lifetime of elemental mercury with latitude $[26,27]$. Relatively few observations of atmospheric $\mathrm{Hg}$ have been carried out in the Southern Hemisphere. The few observations to date, with the exception of those at Cape Point in South Africa [28] and some oceanographic campaigns, have mostly been carried out near to, or downwind of, major sources. This includes mining, industrial facilities and biomass fires. For nearly all South American observations, measured TGM concentrations were substantially greater than the accepted global background level [29]. Having the above in mind this chapter aims to provide an overview of a) major processes affecting the mercury cycle between the atmosphere and aquatic and terrestrial ecosystems, b) mercury emissions from natural and anthropogenic sources, c) spatial and temporal distributions and trends of mercury species over the northern and southern hemispheres, d) the chemical and physical processes 
affecting the transport and fate of atmospheric mercury, and e)major policy frameworks aiming to control the impact of mercury on human health and ecosystems.

\section{The mercury cycle}

The global mercury cycle is a natural phenomenon which has been enhanced by anthropogenic activity. Mercury enters the atmosphere, oceans, rivers and soils, and eventually also biota from a number of natural processes. The most important of these is volcanic activity, but the weathering of $\mathrm{Hg}$ bearing rocks also adds to the global environmental $\mathrm{Hg}$ burden over time. The natural $\mathrm{Hg}$ cycle should not be considered to be constant in time, as major volcanic eruptions can, over a short period, add quite significant quantities of $\mathrm{Hg}$ to the atmosphere which is then deposited over time to both aquatic and terrestrial surfaces. Clearly the spatial distribution of $\mathrm{Hg}$ is not homogeneous over the earth either, depending as it does on the location of volcanic sources and $\mathrm{Hg}$ rich soils. Mercury released to the atmosphere and oceans is transported, relatively quickly in the atmosphere and significantly less so in the oceans, and it is the atmosphere therefore that is the major pathway by which $\mathrm{Hg}$ is distributed around the globe. The apparent residence time of $\mathrm{Hg}$ in the atmosphere (with its present day composition) is around 8 months [30], although it does vary, depending on source location and atmospheric conditions. Mercury has enough time to redistributed on a global scale, and $\mathrm{Hg}$ is currently found to have a very uniform background concentration on a hemispheric scale [29], although as discussed below this may be due to rapid cycling at interfaces rather than uninterrupted transport from source to receptor [31]. The global scale redistribution of emitted $\mathrm{Hg}$ is aided by its exchange between environmental compartments. Mercury in the atmosphere can be deposited to the oceans or to land, but this deposited $\mathrm{Hg}$ can be re-emitted to the atmosphere, hours, weeks or decades later. Mercury taken up by fish or trees for example, may be released again years or centuries later as the dead organism decays. Thus the presence of $\mathrm{Hg}$ in the environment is prolonged by its continual passing from one environmental compartment to another until eventually, $\mathrm{Hg}$ associated with marine particulate matter, settles and is buried in deep ocean sediments [32,33].

The major exposure pathway to $\mathrm{Hg}$ contamination for humans is through the consumption of predatory fish. As stated above however, the major transport / redistribution pathway for environmental $\mathrm{Hg}$ is the atmosphere. The relationship between atmospheric deposition and the concentrations of $\mathrm{Hg}$ in aquatic environments, as well as that between $\mathrm{Hg}$ concentrations in water and those in fish need to be understood. One important factor in this exchange between the atmosphere, water and biota is the time that it takes for one environmental compartment to respond to a change in the state of another. For example, if a lake is considered, there is a balance between atmospheric input, $\mathrm{Hg}$ concentration (and speciation) in the water, $\mathrm{Hg}$ concentration (and speciation) in sediments at the bottom of the lake and the $\mathrm{Hg}$ concentration in the lake biota both in the water and in the sediments. Reducing the $\mathrm{Hg}$ deposition to the lake from the atmosphere will set off a process of re-equilibration of the $\mathrm{Hg}$ present in the system between the various environmental reservoirs and it is possible to envisage over time that the average quantities of $\mathrm{Hg}$ in each of them will diminish. The extent of the reduction of $\mathrm{Hg}$ concentrations in fish is of interest as this is directly related to possible health risks from exposure, as is the time required for this new steady state to be attained. This is an oversimplification of the actual problem, larger (older) fish would generally have higher $\mathrm{Hg}$ concentrations in their tissues, and other physico-chemical factors may change the rate at which $\mathrm{Hg}$ is exchanged between environmental compartments and the form in which it is present. However it illustrates the point that because of the significant, order or orders of magnitude differences in the time scales of the processes (transport, exchange, re-exchange and removal), within the environmental global $\mathrm{Hg}$ cycle; it is not a simple matter to conclusively link sources to receptors, or changes in the $\mathrm{Hg}$ burden of one environmental compartment to changes in another. This point is discussed further later in Sect. 2.6).

For at least three thousand years or so mankind has perturbed the natural, global $\mathrm{Hg}$ cycle. Cinnabar and mercury itself were extracted and used ceremonially in a number of ancient cultures, in South America, Asia, Europe and North Africa. Mercury was used by alchemists in a number of societies, and the Romans used to mine $\mathrm{Hg}$ in significant amounts. Many of these societies were aware of the hazards associated with $\mathrm{Hg}$ and generally used slaves in their mines. For most of this time $\mathrm{Hg}$ added to the 
global environmental burden was the result of $\mathrm{Hg}$ extraction and use, and was mostly on a limited scale. The emissions from these activities were generally relatively limited in quantity and rather like natural emissions were mostly from quite distinct geographical locations. During the industrial revolution the previous direct association of $\mathrm{Hg}$ emission with mostly metallurgical processes began to change. Mercury use, and therefore emission became more widespread across industry and manufacture, and, as we now know, the coal combustion that provided the energy required by industry, was itself a source of $\mathrm{Hg}$ emission, due to the trace amounts of $\mathrm{Hg}$ found in coal.

\subsection{The present day atmospheric $\mathrm{Hg}$ cycle}

The perturbation caused by industrial activity is estimated to have increased the global atmospheric $\mathrm{Hg}$ burden by 3 to 5 times its pre-industrial level [32,34]. The increased deposition of $\mathrm{Hg}$ from the atmosphere has resulted in an estimated doubling of the emissions from land and oceans. The current contribution of oceanic $\mathrm{Hg}$ emissions to the atmosphere is roughly the same as that from anthropogenic sources [2,4], and possibly nearly $90 \%$ of oceanic emissions are re-emissions [35]. The global background concentration of atmospheric $\mathrm{Hg}$ differs between the northern and southern hemispheres. This fact is indicative of both the greater industrial activity in the northern hemisphere and also the atmospheric lifetime of mercury which, while it is long enough for $\mathrm{Hg}$ to be evenly distributed hemispherically, it is not long enough to survive the longer times required for cross equator transport. The blocking of atmospheric tracer transport across the equator does not precisely coincide with either the geographical equator or the position of the ITCZ, however it is very distinct and has been coined "the chemical equator" [36]. In terms of the interaction of the atmospheric $\mathrm{Hg}$ cycle and the oceanic $\mathrm{Hg}$ cycle this hemispheric background concentration difference is a very important clue to the exchange of $\mathrm{Hg}$ between the atmosphere and the oceans. The continued higher atmospheric concentration of $\mathrm{Hg}$ in the northern hemisphere suggests that the $\mathrm{Hg}$ deposited to the oceans does not remain in the ocean long enough for the global ocean circulation to redistribute $\mathrm{Hg}$ evenly across the globe. This points to a multi-hop transportation mechanism for $\mathrm{Hg}$, where deposition and re-emission occur on a reasonably short time-scale [26], which tallies with the estimate of [35] that $90 \%$ of $\mathrm{Hg}$ deposited to the oceans is re-emitted. The impact of reductions in emissions to the atmospheric $\mathrm{Hg}$ burden was demonstrated in post-Soviet Europe when a large number of coal fired power stations in the former Eastern-bloc were shut down. This led to a relatively rapid sudden and quantitatively significant regional decrease in $\mathrm{Hg}$ emissions to the atmosphere. Observations of atmospheric $\mathrm{Hg}$ concentrations and $\mathrm{Hg}$ deposition in precipitation form monitoring sites in the Netherlands, Germany, Norway and Sweden, showed that in spite of no change in the measured Total Gaseous Mercury (TGM) concentration, there was a clear decrease in $\mathrm{Hg}$ deposition in rainfall, over the period 1995-2002 [37]. Earlier measurements [38] showed that TGM values at these sites had decreased until the early 90s, when they levelled off, suggesting that TGM became more influenced by the $\mathrm{Hg}(0)$ global background, while deposition continued to be influenced by by regional emissions of $\mathrm{Hg}(\mathrm{II})$ and $\mathrm{Hg}(\mathrm{P})$. The opposite scenario, of above background concentrations of $\mathrm{Hg}(0)$, influenced by regional emissions is seen at Hedo Station, Okinawa, where outflow from Asia can be detected [39]. The same outflow also influences concentrations of $\mathrm{Hg}$ at the Mount Bachelor Observatory in Oregon [8]. Thus the atmosphere, on a regional scale, actually appears to respond quite rapidly to changes in emissions. However, the lack of longterm $\mathrm{Hg}$ concentration and deposition data mean that up until now there are limited instances where this supposition can be tested.

\subsection{The present day Oceanic Hg Cycle}

The anthropogenic perturbation of the natural oceanic burden of $\mathrm{Hg}$ in ocean waters is less than that of the atmospheric burden, and differs between surface intermediate and deep waters, it also varies notably with geographic location. But the oceans are fundamental in the global Hg cycle [31,32,34, $35,40]$. They are a both a source and a sink for atmospheric $\mathrm{Hg}$, a link between the atmosphere and the final fate of $\mathrm{Hg}$ in deep sediments, a reaction vessel where $\mathrm{Hg}$ is transformed, that is oxidised, reduced and methylated, and the point at which $\mathrm{Hg}$ enters the food web. Mercury in oceans is found 
as $\mathrm{Hg}(0), \mathrm{Hg}(\mathrm{II})$, methylmercury and dimethylmercury as well as associated with particulate matter, sometimes referred to as colloidal mercury. The methylation processes at work in the oceans are not fully understood but is known to occur in the sediments of coastal shelf and esturine regions. It also occurs within the water column and at deep ocean hydrothermal vents, the amount of $\mathrm{MeHg}$ in water varies from 5-35\% of the total. The reduction of deposited $\mathrm{Hg}$ (II) to $\mathrm{Hg}(0)$ by biological and photolytic processes in the surface waters of the oceans plays an extremely important role in the atmospheric redistribution of $\mathrm{Hg}$ around the globe. A recent modelling study of the oceanic $\mathrm{Hg}$ cycle which took into account the surface, intermediate and deep waters of the major ocean basins, and the vertical and lateral movement of water between them, including major zones of upwelling and areas of overturning, indicated that the ocean $\mathrm{Hg}$ burden is as yet far less perturbed than that of the atmosphere [32]. The same study also highlighted the importance of direct from rivers which directly impact estuaries and shallow continental shelf regions. The ocean compartment most perturbed from pre-industrial times in the model was the surface North Atlantic (and Mediterranean) whilst the deep Pacific was the least influenced.

\subsection{Fresh water Hg cycling}

Lake sediments and wetland areas are important areas of $\mathrm{Hg}$ methylation. These areas are influenced by both atmospheric deposition and run-off from their surrounding watersheds. Numerous lakes in $\mathrm{N}$. America have advisories regarding the consumption of fish caught in lakes, and these lakes are by no means all influenced by major local sources. The $\mathrm{Hg}$ cycle in lake environments is more complex than the ocean and methylation can be influenced by sediment type, dissolved organic carbon content, $\mathrm{pH}$, iron, and sediment type and structure. Of all factors though the most important is often sulphate as many of the bacteria that methylate $\mathrm{Hg}$ are sulphate reducing bacteria [41]. A coupled ecosystem modelling study of the effect of decreased $\mathrm{Hg}$ deposition on different freshwater ecosystem types, suggests that where the major mercury input is direct atmospheric deposition, the response of the system to the changes is most rapid, whereas those ecosystems receiving $\mathrm{Hg}$ from the watershed respond more slowly [42]. All the ecosystem types studied however, showed an initial rapid decline of 20 to $60 \%$ in $\mathrm{Hg}$ concentrations over one to three decades. A recent study suggests that the relationship between atmospheric inorganic $\mathrm{Hg}$ and methylmercury in fish is linear and theat the response to changes in deposition occurs rapidly (within weeks) [43].

\subsection{Terrestrial Hg cycling}

With the exception of areas which are rich in $\mathrm{Hg}$ bearing minerals, most $\mathrm{Hg}$ in soils and vegetation comes originally from atmospheric deposition, both wet and dry. $\mathrm{Hg}$ (II) deposits on leaves and from the atmosphere, whereas uptake by plants of $\mathrm{Hg}(0)$ is thought to occur through the stomata. Most $\mathrm{Hg}$ in the terrestrial system however is in soils rather than biomass, and it is generally bound to organic substances such as compounds with reduced sulphur groups. Mercury reaches the soil in vegetated areas via direct precipitation and throughfall. Litterfall also adds to the $\mathrm{Hg}$ contained in soils. Mercury contained in soils can be reduced, this is generally thought to be an abiotic process and appears to be influenced by temperature and solar radiation. Some evidence that $\mathrm{Hg}$ emission is enhanced from dry soil has been found. It has recently been proposed that a significant part of the $\mathrm{Hg}$ (II) deposited to terrestrial surfaces is reduced and rapidly returns to the atmosphere, mirroring then the multi-hop mechanism of distribution of $\mathrm{Hg}$ suggested for the oceanic $\mathrm{Hg}$ cycle. The evidence for this 'promptrecycling' as it has been termed [33] comes from measurements made during the METALLICUS experiment [44], from observations of $\mathrm{Hg}$ fluxes (and $\mathrm{Hg}$ concentrations in snow) after AMDEs as well as indirectly from modelling studies. Natural emissions and terrestial cycling are further discussed in Sect. 3.1.3.

\subsection{Putting numbers on burdens and fluxes}

The recent review by Selin [31] summarises the efforts made so far to assess the magnitudes of the amounts of $\mathrm{Hg}$ in environmental compartments and the fluxes between them. The estimated 


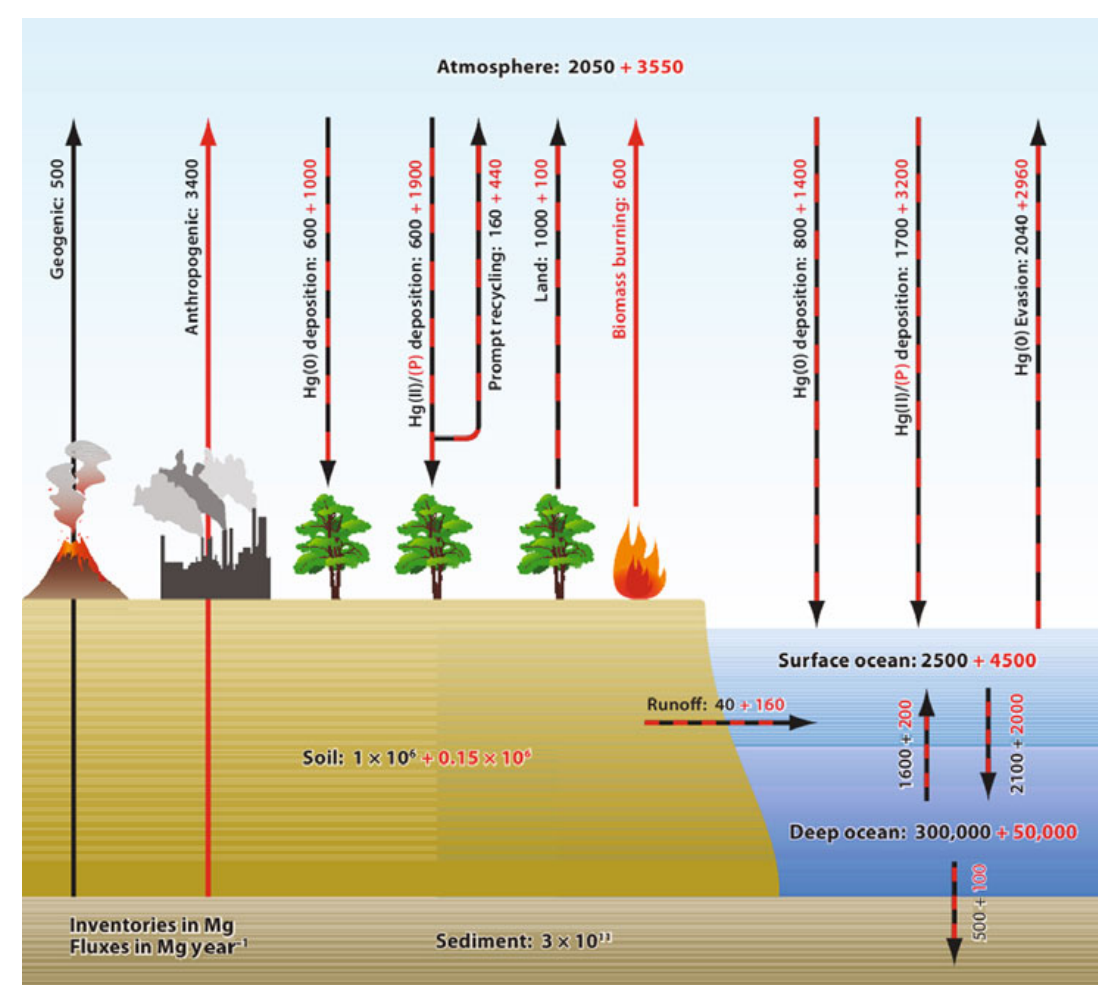

Fig. 1. The most recent esimate of the environmental pre-industrial and present day $\mathrm{Hg}$ burden and the natural and anthropogenic annual fluxes $\left(\mathrm{Mg} \mathrm{year}^{-1}\right)$. Pre-industrial burdens and fluxes are in black, the anthropogenic burdens and fluxes in red, reproduced from Selin [31].

burdens in these estimates do not vary wildly, however the fluxes between them appear to be less well constrained. The estimates of the pre-industrial atmospheric $\mathrm{Hg}$ burden range between 1,600 and $2,050 \mathrm{Mg}$, while the anthropogenic atmospheric contribution ranges between 3,400 and $4,000 \mathrm{Mg}$, to give totals between 5,000 and 5,600 Mg. Estimated pre-industrial fluxes of $\mathrm{Hg}$ to the atmosphere from the ocean vary between 400 and $2,040 \mathrm{Mg} \mathrm{year}^{-1}$, while the estimates of the anthropogenic component of the ocean to atmosphere $\mathrm{Hg}$ flux span 400 to $2,960 \mathrm{Mg} \mathrm{year}^{-1}$. The major differences in the Hg flux estimates to date do not depend on assessments of total burdens but the ease and rapidity with which $\mathrm{Hg}$ is cycled between environmental compartments. Generally speaking it seems that the more recent the $\mathrm{Hg}$ global cycle estimate the higher the exchange fluxes, reflecting the growing understanding of the the dynamic way in which $\mathrm{Hg}$ is cycled in the environment, and also an ever increasing technical capacity to determine $\mathrm{Hg}$ concentrations and fluxes in the environment. The most recent assessment of the global $\mathrm{Hg}$ cycle by Selin [33] is reproduced graphically in Fig. 1. It should be noted that of all the assessments to date this one has the highest burdens and the most active cycling between environmental compartments.

\subsection{The response time of environmental compartments to flux changes}

The global $\mathrm{Hg}$ cycle has not reached steady state following the anthropogenic perturbation which it has undergone and which it is still experiencing. Estimates vary for the time which $\mathrm{Hg}$ once emitted remains available in the environment before being buried, but whether it is 3000 years (ref) or 10,000 years (ref), makes little difference when we consider that $\mathrm{Hg}$ emissions have only changed significantly since the beginning of the industrial revolution. However as discussed above changes in emissions do result in changes in atmospheric $\mathrm{Hg}$ concentrations and deposition fluxes within a few years [22,39], it seems likely also that the $\mathrm{Hg}$ concentrations observed in the northern Atlantic surface are at least 
in part attributable to anthropogenic emissions in North America and Europe. It is important to know what to expect in terms of ecosystem response from any proposed emission reduction strategy. In their modelling study of the ocean cycle of $\mathrm{Hg}$ Sunderland et al. [32] estimated how close the current $\mathrm{Hg}$ concentrations are to their steady state values and also how long it would take, if emissions continue at their present rate, for each ocean compartment that they considered. The estimated times varied from 10 to 1000, years. This information is useful, because although monitoring atmospheric $\mathrm{Hg}$ concentrations would in the first instance permit the evaluation of emission reduction, it is in marine and fresh water ecosystems that the concentration of $\mathrm{Hg}$ matters most. Understanding the time lag between emission change, atmospheric response and aquatic ecosystem response would therefore be essential in judging the efficacy of any future emissions reduction policy.

\section{Emissions from natural and anthropogenic sources}

Assessments of mercury emission from natural and anthropogenic sources increase their attraction to researchers as of the uncertainty in the estimate of origin and distribution in time and space of mercury release to the atmosphere. Twenty years of research have experienced significant advances in assessment of mercury emission from anthropogenic sources, whereas a small attention was kept on mercury emission from natural sources. In details, earlier studies of global mercury emissions were aimed primarily to assess the contribution from anthropogenic sources, namely coal, oil and wood combustion, solid waste incineration, pyrometallurgical processes $[1,5,45,46]$ as well as artisanal small scale gold mining $[47,48]$. On the other hand, several studies have estimated emissions from volcanoes $[3,49,50]$, re-emission from oceans and surface waters [34], top soil and vegetation [51] and forest fires [52-55]. More recently, assessments of mercury emissions to the global atmosphere have included the contribution of the most important anthropogenic and natural sources $[2,6,56,57]$. This section of the chapter reports most recent advances on global assessments on mercury emissions from natural and anthropogenic sources.

\subsection{Natural sources}

The estimate of mercury emissions from natural sources include the contribution from primary natural sources and reemission processes of historically deposited mercury over land and sea surfaces. The mercury emitted from volcanoes, geothermal sources and topsoil enriched in mercury pertains to primary natural sources, whereas the re-emission of previously deposited mercury on vegetation, land or water surfaces is primarily related to land use changes, biomass burning, meteorological conditions and exchange mechanisms of gaseous mercury at air-water/top-soil/snow-ice pack interfaces [4,20].

\subsubsection{Volcanoes and geothermal activities}

The contribution of volcanoes varies over time depending whether they are in a degassing or eruption phase. The $\mathrm{Hg} / \mathrm{SO}_{2}$ mass ratio is generally adopted to estimate mercury emissions, though this approach is very controversial because of the paucity of relevant data and their variability [49,50]. On average, volcanoes and geothermal activities release about $90 \mathrm{Mg} \mathrm{year}^{-1}$ of mercury to the atmosphere [4], accounting for nearly $2 \%$ of the total contribution from natural processes.

\subsubsection{Oceans, seas and lakes}

Several studies suggest that the evasion of elemental mercury from surface waters is primarily driven by (i) the concentration gradient of mercury between the top-water microlayer and air above the surface water, (ii) solar irradiation which is responsible for the photo-reduction of oxidized mercury in the top-water microlayer, and (iii) the temperature of the top-water microlayer and air above the 
Table 1. Global mercury emissions by natural sources estimated for 2008 (from [57]).

\begin{tabular}{llll}
\hline Source & $\begin{array}{l}\text { Mercury } \\
\left(\mathrm{Mg} \mathrm{year}^{-1}\right)\end{array}$ & $\begin{array}{l}\text { Ratio with total } \\
\text { global emissions }(\%)\end{array}$ & $\begin{array}{l}\text { Ratio with total } \\
\text { natural emissions }(\%)\end{array}$ \\
\hline Oceans & 2682 & 35.6 & 51.5 \\
Lakes & 96 & 1.3 & 1.8 \\
$\begin{array}{l}\text { Forests } \\
\text { Tundra/Grassland/Savannah/ }\end{array}$ & 342 & 4.5 & 6.6 \\
$\begin{array}{l}\text { Prairie/Chaparral } \\
\text { Desert/Metalliferous/ }\end{array}$ & 448 & 6.0 & 8.6 \\
$\begin{array}{l}\text { Non-vegetated Zones } \\
\text { Agricultural areas }\end{array}$ & 546 & 7.3 & 10.5 \\
$\begin{array}{l}\text { Evasion after mercury depletion } \\
\text { events }\end{array}$ & 128 & 1.7 & 2.5 \\
$\begin{array}{l}\text { Biomass burning } \\
\text { Volcanoes and geothermal areas }\end{array}$ & 200 & 2.7 & 3.8 \\
TOTAL & & & \\
\hline
\end{tabular}

surface water (air-water interface) [24,58,59]. The evasion of mercury from lake surfaces is generally higher (maximum net evasion of $2.39 \mathrm{ng} \mathrm{m}^{-2}$ hour $^{-1}$ ) than that observed over the sea (range of 1.16$2.50 \mathrm{ng} \mathrm{m}^{-2}$ hour $\left.^{-1}\right)$. On average, coastal waters and the Mediterranean Sea have the highest evasional flux (1.83 and $1.96 \mathrm{ng} \mathrm{m}^{-2}$ hour $^{-1}$, respectively) [24,59]. Recent estimates of total mercury evasion from ocean basins and lakes account for $2778 \mathrm{Mg} \mathrm{year}^{-1}$ (37\% of the emission from natural sources) of net gaseous mercury evasion to the atmosphere [4].

\subsubsection{Topsoils and vegetation}

Mercury emissions from top soils and vegetation are significantly influenced by meteorological conditions, historical atmospheric deposition and the type of vegetation and top soil [60]. Whereas, mercury emissions from vegetation depend upon several factors, including mercury uptake from the atmosphere, atmospheric deposition to foliage and mercury uptake from roots [61]. The proximity of vegetation to natural or anthropogenic sources (hot spots or contaminated sites) may increase its mercury content $[62,63]$. Recent studies show that most of the mercury found in foliage tissue originates from the atmosphere $[64,65]$. Summing up all the net evasional fluxes from all regions and media (Forests, Tundra/Grassland/Savannah/Prairie/Chaparral, Desert/Metalliferrous/Non-vegetated Zones and Agricultural areas) the total net global mercury evasion is $1464 \mathrm{Mg}_{\text {year }}{ }^{-1}$ [4].

\subsubsection{Biomass burning}

Mercury emissions from biomass burning have only recently been considered in regional and global estimates $[52,53,55,66-68]$. The most recent estimate suggests that on a global scale nearly $675 \mathrm{Mg}$ of mercury is released to the atmosphere from biomass burning every year (annual average for the period 1997-2006), which accounts for about 13\% of the total contribution from natural sources [67].

\subsubsection{Global assessment form natural emissions}

The current estimate of mercury emissions from natural processes (primary mercury emissions plus re-emissions), including mercury depletion events, is estimated to be $5207 \mathrm{Mg}$ year $^{-1} \mathrm{Table}^{\text {, which }}$ represent nearly $70 \%$ of the global mercury emission budget. Oceans are the most important sources (36\% on global emission basis) followed by biomass burning (9\%), deserts, metalliferous and nonvegetated zones $(7 \%)$, tundra and grassland $(6 \%)$, forests $(5 \%)$ and evasion after mercury depletion events (3\%). Overall, the relative contribution of terrestrial surfaces is $2429 \mathrm{Mg}$ year $^{-1}$ (47\% on natural 
emission basis) and that from surface waters is $2778 \mathrm{Mg}$ year $^{-1}(53 \%)$. On an area basis, emissions from land (surface $146108 \mathrm{~km}^{2}$ ) are higher than those from the oceans (surface $349108 \mathrm{~km}^{2}$ ). Biomass burning represents $28 \%$ of emissions from land, whereas desert and non-vegetated zones represent $23 \%$ of the total, followed by tundra and grassland with $18 \%$ and forest with $14 \%$. Primary natural sources account for about $4 \%$ of current terrestrial outputs.

\subsection{Anthropogenic sources}

Mercury is released to the atmosphere from a large number of man-made sources, which include fossil-fuel fired power plants, ferrous and non-ferrous metals manufacturing facilities, caustic soda production plants, ore processing facilities, incinerators for urban, medical and industrial wastes, cement plants and chemicals production facilities.

\subsubsection{Fossil fuel combustion}

Fossil fuel-fired power plants are the largest point sources of mercury released to the atmosphere, though other emission sources (e.g. artisanal gold mining) provide an important contribution to the global atmospheric budget $[2,57]$. The combustion of fossil fuels (primarily coal) in stationary combustion facilities represents the most important anthropogenic source of mercury released to the global atmosphere annually (35\% on anthropogenic emission basis) accounting for about $810 \mathrm{Mg} \mathrm{year}^{-1}$, with an important contribution from Asian countries (nearly $50 \%$ of the total). Mercury emissions from oil burning and natural gas, as part of the fossil fuels category, represents a minor contribution compared to that emitted from coal combustion.

\subsubsection{Smelting processes: ferous and non-ferous metals}

Smelting processes to obtain copper, zinc, lead and nickel are known to be large sources of mercury released to the atmosphere, especially in developing countries $[69,70]$. Increasing trends in nonferrous metal production by different processes, especially in new emerging countries, are leading to an increase of mercury releases to the atmosphere. Best estimates of mercury emitted from non-ferrous ore processing are about $310 \mathrm{Mg}$ year $^{-1}$ [71] with a substantial contribution from China which is about $203 \mathrm{Mg} \mathrm{year}^{-1}[72,73]$. Emissions of mercury from primary and secondary pig iron and steel manufacturing plants are related to the overall production and the efficiency of emission control measures. Nearly $43 \mathrm{Mg}$ of mercury per year are released to the environment and no major changes have been reported for this sector during the 1990s and early 2000s[5,20], whereas changes in local economies have led to changes in emissions at country level (e.g. Asia with a $10 \mathrm{Mg}$ year $^{-1}$ increase).

\subsubsection{Cement production}

In cement kilns, coal combustion is a significant source of mercury emissions. Large differences may occur in cement kiln technology, which substantially affect the emission rates and, therefore, mercury emission. On the basis of cement production and implemented technology, estimates of mercury emissions from this source is about $236 \mathrm{Mg}$ year $^{-1}$ [57], with an uncertainty approximately of $\pm 30 \%$ as suggested by Streets et al. [15].

\subsubsection{Chlor-alkali production}

Chlor-alkali plants using mercury cell technology were in operation worldwide in 2007, though in Europe after the approval of recent legislation most of plants have phased out the use of such technology and have been converted to membrane technology $[74,75]$. Due to the process characteristics, 
mercury can be emitted/released from the mercury cell process through air, water and wastes. The total mercury emission in Western Europe was $9.5 \mathrm{Mg}$ in 1998, whereas very different figures have been found for new emerging countries (i.e. India) where this amount is 25 times higher than that used to derive the global best estimate $[73,76]$. The estimate of mercury emissions from this industrial sector is about $163 \mathrm{Mg}$ year $^{-1}$.

\subsubsection{Primary mercury production}

Primary mercury production is another source of mercury released to the atmosphere. At present, productive primary mercury mines are located in Algeria, the People's Republic of China, Kyrgyzstan and Spain, whereas Italy, Mexico, Slovakia, Slovenia and Turkey retain significant reserves as a consequence of previous mining activities. In 2000, nearly $1800 \mathrm{Mg}$ of mercury were produced [77] which led to a global mercury emissions of nearly $50 \mathrm{Mg} \mathrm{year}^{-1}$, which is considered to be very conservative estimate because of the large uncertainty associated with both the amount of mercury and the emission factors used [2].

\subsubsection{Artisanal gold production}

Mercury released from artisanal and small scale gold mining activities (ASGM) is one of the most critical environmental issues, because almost all activities are in developing countries and countries with economies in transition. Current estimates are derived from government data on mercury and gold exports/imports, field reports and analysis of the production and technology used. As result, ASGM is active in 70 countries, with $1000 \mathrm{Mg} \mathrm{year}^{-1}$ of mercury released to the environment from this particular source. Nearly $400 \mathrm{Mg} \mathrm{year}^{-1}$ (17\% of total anthropogenic emissions) is the amount of mercury released to the atmosphere from ASGM, which includes $350 \mathrm{Mg} \mathrm{year}^{-1}$ from amalgam burning and $50 \mathrm{Mg}_{\text {year }}{ }^{-1}$ from tailings [70].

\subsubsection{Waste generation}

Hazardous or non-hazardous waste generation is strictly related to the consumption of goods and the recycling processes adopted in the region or country. Mercury in industrial wastes mostly originates from the phasing out of mercury from industrial processes and mercury-containing products. The most important source that generates wastes containing mercury is the chlor-alkali industry which emits $9.4 \mathrm{Mg}$ as upper boundary with a very low uncertainty (lower value is 8.4) [6]. Mercury in municipal waste is primarily related to consumer products. It can be released from batteries, dental applications, measurement and electronic devices, lamps and other minor applications. The estimate was made according to distribution coefficients pertaining to disposal (i.e. release by breaking, incineration, landfilling, recollection) and to different emission coefficients. For some European Countries, Mukherjee et al. [75] estimated that $240 \mathrm{Mg}$ per year is the amount of mercury in waste related to consumer products, however, mercury emissions from this sector have not been estimated yet. Also slag produced from waste incineration processes could be a mercury source as it has mercury concentration from 0.02 to $7.75 \mathrm{mg} \mathrm{kg}^{-1}$. The total mercury mobilized in slag from waste incinerators in Europe (EU-15 + 3 non-EU countries) varies between 24 and $54 \mathrm{Mg}$, which is partially released to the atmosphere [75]. Mercury in medical waste has not been yet estimated in many countries, as a consequence a global assessment of mercury emissions from this particular source has not been made yet, and emissions are often lumped in the overall waste incinerators estimate [69]. Summing up all known contributions from the incineration of urban, medical and industrial wastes the global mercury emissions to the atmosphere from this emission source category is $187 \mathrm{Mg}$ year $^{-1}$.

\subsubsection{Coal-bed fires}

Coal-bed fires have occurred since prehistoric times and were initiated by natural causes including spontaneous combustion, lightning strikes and forest fires. However, they have proliferated worldwide 
Table 2. Global mercury emissions from anthropogenic sources (reproduced from Pirrone et al. [57]).

\begin{tabular}{llll}
\hline Source & $\begin{array}{l}\text { Mercury } \\
\left(\text { Mg year }^{-1}\right)\end{array}$ & $\begin{array}{l}\text { Ratio with total } \\
\text { global emissions }(\%)\end{array}$ & $\begin{array}{l}\text { Ratio with total } \\
\text { anthropogenic emissions }(\%)\end{array}$ \\
\hline Coal and oil combustion & 810 & 10.8 & 34.9 \\
Non-ferrous metal prod. & 310 & 4.1 & 13.4 \\
Pig iron and steel prod. & 43 & 0.6 & 1.9 \\
Cement production & 236 & 3.1 & 10.2 \\
Caustic soda production & 163 & 2.2 & 7.0 \\
Mercury production & 50 & 0.7 & 2.2 \\
Artisanal gold mining prod. & 400 & 5.3 & 17.2 \\
Waste disposal & 187 & 2.5 & 8.1 \\
Coal bed fires & 32 & 0.4 & 1.4 \\
VCM production & 24 & 0.3 & 1.0 \\
Other & 65 & 0.9 & 2.8 \\
TOTAL & 2320 & 30.8 & 100.0 \\
\hline
\end{tabular}

since the Industrial Age, primarily as a consequence of anthropogenic activities [78]. Today, tens of thousands of uncontrolled coal fires are active in the world, which emit mercury among other compounds [79]. The amount of mercury released annually to the atmosphere by uncontrolled coal-bed fires is $32 \mathrm{Mg}$ ( $1 \%$ of total anthropogenic emissions).

\subsubsection{Vinyl chloride monomer production}

Vinyl chloride monomer (VCM) is an intermediate feedstock in the production of polyvinyl chloride (PVC), which production process uses sometimes mercuric chloride on carbon pellets as a catalyst. Mercury emissions have been estimated from global production of PVC [57], showing $24 \mathrm{Mg}$ of mercury annually released to the atmosphere.

\subsubsection{Global assessment form anthropogenic emissions}

Summing up the contributions from anthropogenic sources, nearly $2320 \mathrm{Mg}$ of mercury is released annually to the global atmosphere (31\% of total global emissions) Table 2 . The present assessment shows that the majority of mercury emissions originate from combustion of fossil fuels $(11 \%)$, followed by artisanal small scale gold mining (5\%), non-ferrous metal production (4\%), cement production $(3 \%)$, caustic soda production $(2 \%)$, waste incineration $(2 \%)$ and pig-iron production $(1 \%)$. In the last decades a considerable amount of research has been done to improve mercury emission inventories at country level, including those countries with economies in transition [73,80]. Recent estimates show that Europe and North America are reducing their contribution to the global mercury burden, whereas emissions in Asia are increasing, the latter is primarily driven by the upward trend of energy demand that in the last decade has grown at a rate of 6 to $10 \%$ per year Figure 2.

\subsubsection{Trend in global emissions}

A recent overview on trends of global emissions [81] shows an increase of total emission which is not supported by the evidence that most countries have dramatically reduced trade in, and consumption of, mercury [82] Table 3. Mercury supply in 1985 was near $6000 \mathrm{Mg}$ while it was near $4000 \mathrm{Mg}$ in 2006 [82]. On the other hand an increase in emissions was observed, which can be ascribed to the improvement of estimates by integrating new sources or by improving our knowledge on previously estimated sources. As widely recognized, mercury emission estimates are subjected to uncertainty [9, 46, 72, 83-85]. 
1990

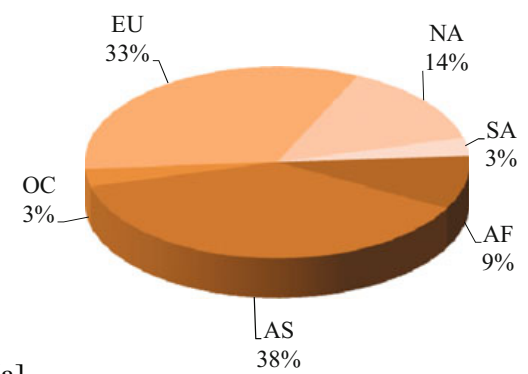

[a]

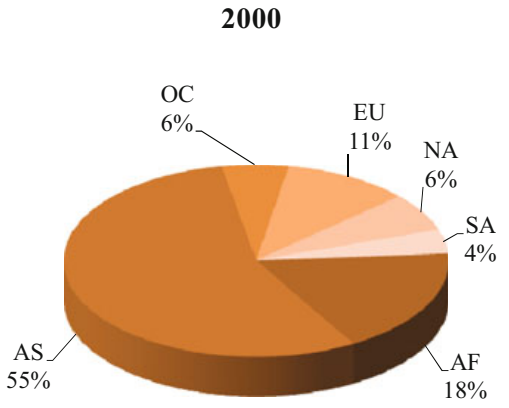

[c]
1995

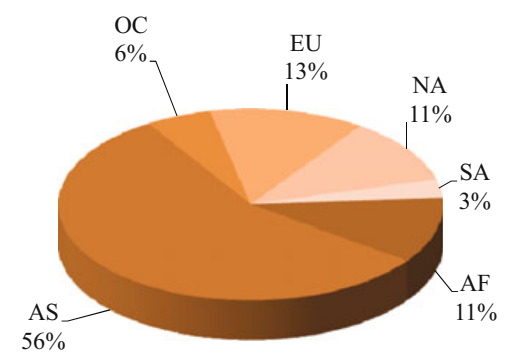

[b]

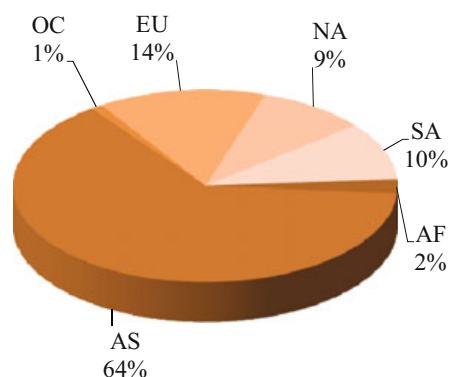

[d]

Fig. 2. Trends of global anthropogenic emissions by region based on (a) Pirrone et al. [1], (b) Pacyna et al. [46], (c) Pacyna et al. [5], (d) Pirrone et al. [57]. Data reported in Fig. 2(d) are for most contributing countries as reported in Pirrone et al., [57]. AF, Africa; AS, Asia; EU, Europe; NA, North America; OC, Oceania; SA, South America. Reproduced from Pirrone et al. [57].

Table 3. Comparison of mercury emissions $\left(\mathrm{Mg} \mathrm{year}^{-1}\right)$ as reported in the literature (reproduced from Pirrone et al., [81]).

\begin{tabular}{llllllllll}
\hline Reference year & 1985 & 1990 & 1995 & $2000^{1}$ & 2006 & $2000 / 2005$ & 2005 & $2000 / 2005$ & 2005 \\
\hline $\begin{array}{l}\text { Anthropogenic } \\
\text { emissions }\end{array}$ & 1989 & 2217 & 2427 & 2254 & $1894^{2}$ & 2501 & 1926 & 2909 & 2320 \\
Reference & {$[1]$} & {$[1]$} & {$[46]$} & {$[5]$} & {$[15]$} & {$[27]$} & {$[6]$} & {$[2]$} & [57] \\
Reference year & 1999 & 2002 & 2002 & 2004 & 2007 & 2008 & 2008 & & \\
\hline $\begin{array}{l}\text { Natural emissions } \\
\text { Reference }\end{array}$ & 5300 & 4200 & 3600 & 4278 & 4800 & 4532 & 5207 & & \\
\hline
\end{tabular}

${ }^{1}$ Updated with Pacyna et al. [5]; ${ }^{2}$ Without considering biomass burning; the estimate is based on emitting sectors instead of source categories.

\subsubsection{Uncertainty of assessments}

Although estimates of current anthropogenic emissions for many other pollutants are cited with a greater precision, an uncertainty of $\pm 30 \%$ for major industrial sources of mercury is widely accepted [6]. Mercury emission estimates are directly related to the emission factors and activity levels ascribed to major anthropogenic activities, and the uncertainties in these two factors have an additive influence on the overall uncertainty associated with emission estimates [57]. In addition, a specific concern is for regions that are inadequately described in terms of point sources (Africa, South America) or exhibit unusually high uncertainties (Asia). 


\section{Spatial distribution of mercury species in the atmosphere}

Long-term atmospheric $\mathrm{Hg}$ monitoring and additional ground-sites are important in order to provide datasets which can give new insights and information about the worldwide trends of atmospheric $\mathrm{Hg}$. A successful $\mathrm{Hg}$ monitoring network, would need to consist of a relatively small number of "intensive" sites, where the full range of measurements are made (i.e., Hg speciation in ambient air and dry deposition estimation, event-based wet deposition and fluxes, as well as ancillary parameters and detailed meteorology), and a larger number of "cluster" sites where only weekly wet deposition samples are collected. The cluster sites would allow for integration between the intensive sites and examine the effects of local and regional conditions, while the intensive sites would provide the detailed information needed to calibrate and test global and regional $\mathrm{Hg}$ models. Existing measurement networks are however not sufficient because of the lack of (a) observations of all forms of $\mathrm{Hg}$ in ambient air and in both wet and dry deposition; (b) co-located long-term measurements of $\mathrm{Hg}$ and other air pollutants; (c) representation of sites in the free-troposphere of both Southern and Northern Hemisphere; and (d) measurement sites that allow a careful investigation of inter-hemispheric transport and trends in background concentrations. Mercury concentration measurements in ambient air of documented and accepted quality are available from the mid 1970s and the mid 1990s for the Northern and Southern Hemispheres, respectively.

\subsection{Mercury measurements in Europe}

Continuous monitoring datasets exist for the time period 1998 to 2004 for two coastal background sites, Mace Head, on the West coast of Ireland and the Zingst peninsula on the southern shore of the Baltic Sea. Automated TGM measurements have been carried out and an evaluation of these two datasets has been published by [86]. Between 1998 and 2004 the annually averaged TGM concentrations measured at Mace Head $\left(1.74 \mathrm{ng} \mathrm{m}^{-3}\right.$ and Zingst $\left(1.64 \mathrm{ng} \mathrm{m}^{-3}\right)$ remained fairly stable. For both stations higher concentrations were detected during the winter months and lower concentrations during summer. Since Mace Head is located at the European inflow boundary and, therefore, considered to be less influenced by continental emissions, an unexpected West to East gradient was observed. No local anthropogenic $\mathrm{Hg}$ sources exist near the Mace Head station, thus, suggesting the important role of enhanced emissions from the sea. International programmes such as, the UN-ECE's European Monitoring and Evaluation Programme (EMEP) have made substantial efforts to establish data centres and quality control programmes to enhance integration of air quality measurements from different national and regional networks, and to establish observational sites in under-sampled remote regions around the world. Extensive evaluation of $\mathrm{Hg}$ measurements in air and precipitation at EMEP and OSPAR stations has been carried out by Wängberg et al. [37]. These data were obtained at coastal sites mainly around the North Sea and originate from Ireland, Netherlands, Germany, Norway and Sweden. The major finding was that a reduction in deposition (10-30\%) has occurred, probably due to emission decreases in Europe. Nodecreasing trend in TGM was observed during the 1995-2002 period. The authors suggest that a plausible explanation is that European TGM emission reductions may be compensated for by increasing emissions in other northern hemispheric regions. Table 4 shows the comparison between average $\mathrm{Hg}$ species concentrations observed at 10 sites in Europe. Table 4 reports $\mathrm{TGM}, \mathrm{Hg}(\mathrm{P})$ and $\mathrm{Hg}(\mathrm{II})$ measurements obtained during four synchronized seasonal field campaigns from 1998 to 1999 at 10 coastal sites in the Mediterranean Region (5 sites) and in North Europe (5 sites) during the EU MOE-MAMCS project. The project results revealed that TGM was slightly higher in the Mediterranean, but also that $\mathrm{Hg}(\mathrm{P})$ and $\mathrm{Hg}(\mathrm{II})$ concentrations were significantly higher at Mediterranean sites compared to northern Europe, even though the density of industrial and urban centres is higher in northern compared to southern Europe [20,21,23,24,87]. The most probable interpretation is that higher emission rates from the Mediterranean sea coupled with enhanced chemical and physical transformation processes occurring in the MBL lead to local production of RGM and $\mathrm{Hg}(\mathrm{P})$ [87-89]. The enhanced re-emission fluxes of $\mathrm{Hg}$ from the sea surface are driven primarily by higher solar radiation, humidity and temperature in the Mediterranean basin, when compared to more northern seas. As in the Mediterranean MBL, high $\mathrm{Hg}(\mathrm{II})$ concentrations have also been observed in the MBL of the North Atlantic (Bermuda) [90] and of the Pacific ocean [91]. 


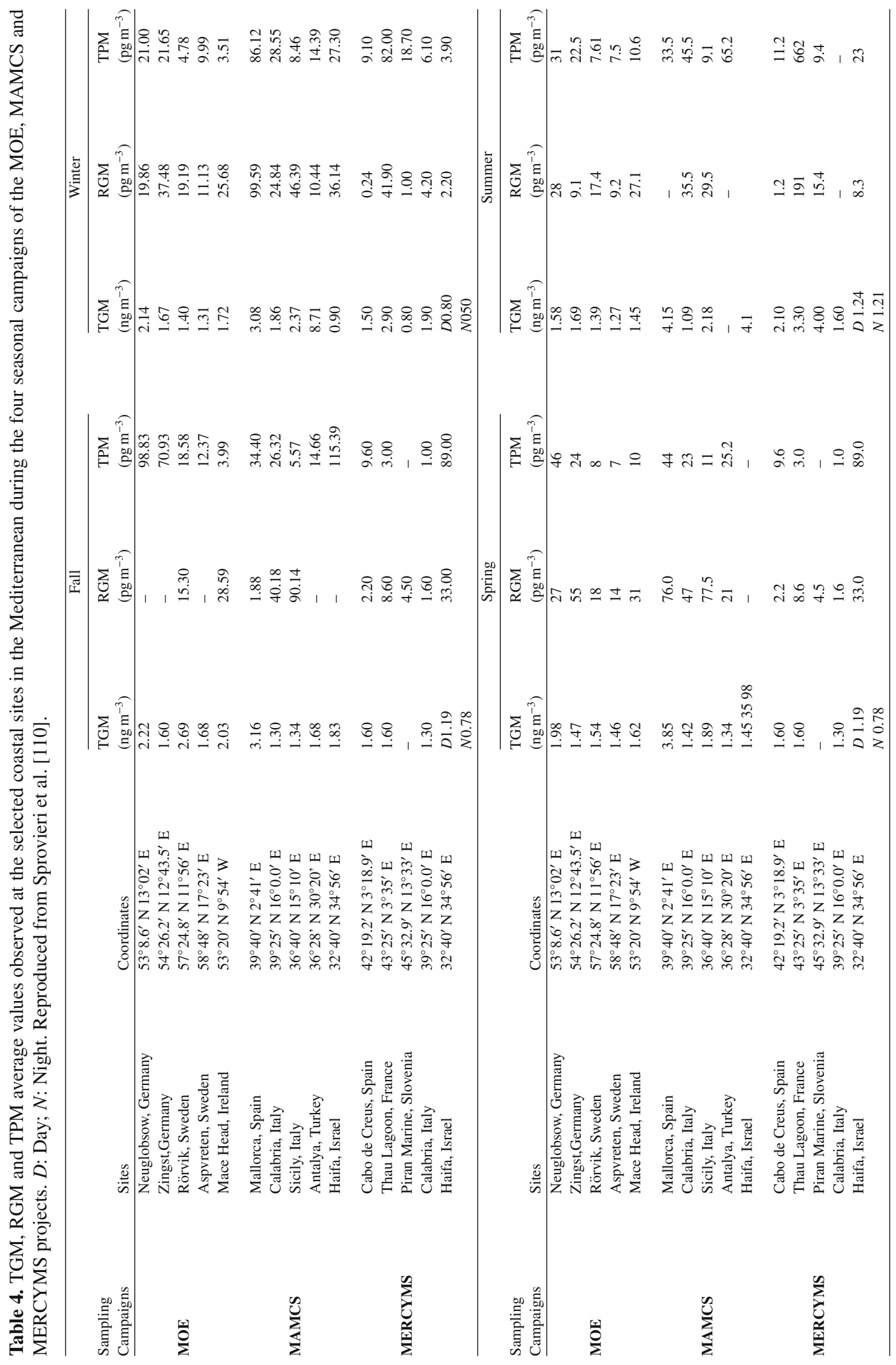




\subsection{Hg measurements and air/water exchange over Atlantic, Pacific and Arctic Oceans}

The lack of knowledge of the magnitude of $\mathrm{Hg}$ exchange processes is one of the main factors affecting the overall uncertainty associated with the assessment of net fluxes of $\mathrm{Hg}$ between the atmospheric and marine environments. The transformations of $\mathrm{Hg}$ and its compounds that take place in marine water are of crucial importance in understanding the way in which $\mathrm{Hg}$ released into the atmosphere is eventually incorporated into biota, thereby becoming a risk for human health and ecosystems. Hg measurements, along with flux estimates, have been performed over the world's oceans and seas and most results from these studies show that the water is saturated in $\operatorname{Hg}(0)$, thus, the resultant flux of $\operatorname{Hg}(0)$ is from the ocean to the atmosphere. The first shipboard measurements during north-south cruises over the Atlantic Ocean were made between 1977-1980 [92,93] and repeated in 1990 and 1994 [94,95]. In 1996, Lamborg et al. [96] performed $\mathrm{Hg}$ measurements in the south and equatorial Atlantic Ocean from Montevideo, Uruguay to Barbados. The open-ocean samples recorded a distinctive inter-hemispheric gradient, which is consistent with a long-lived trace gas emitted to a greater extent in the Northern Hemisphere [40]. When latitude is taken into account, the TGM concentrations measured on board ship are also comparable to measurements at remote coastal sites such as Mace Head (Ireland), Cape Point (South Africa) and Lista (Norway) [16,97]. The agreement shows that a combination of long-term measurements at several sites with snapshots of latitudinal distribution obtained by ship measurements is feasible and may provide information about the worldwide trends of atmospheric Hg. The gradient and higher variability observed in the Northern Hemisphere suggests that the majority of emissions and re-emissions are located in the Northern Hemisphere. $\mathrm{Hg}$ (II) measurements by Mason et al. [90] represented the first reported measurements in the remote ocean MBL. $\mathrm{Hg}$ (II) showed a clear and consistent diurnal cycle with maxima up to $27 \mathrm{pg} \mathrm{m}^{-3}$ and minima often at the instrument detection limit, suggesting that $\mathrm{Hg}$ (II) formation is linked to photo-chemical processes. Similarly, a diurnal fluctuation in $\mathrm{Hg}$ (II) was found during a North Pacific cruise [91], although concentrations were much higher, up to $100 \mathrm{pg} \mathrm{m}^{-3}$. For the subtropical North Pacific, the average $\mathrm{Hg}(\mathrm{II})$ concentration was $11.8 \mathrm{pg} \mathrm{m}^{-3}$, which was somewhat higher than that found in the North Atlantic, showing however, the same degree of variability. Mercury measurements over the Pacific Ocean started in the early 1980s. There are insufficient data to extrapolate small variations in TGM concentrations over time for the North Pacific [40,98] and to evaluate differences between seasons and latitude. In the Atlantic Ocean, only few of these studies focused on measurements of DGM at offshore sites. Mason et al. (1998) carried out measurements in the North Atlantic Ocean, while Mason and Sullivan [99] measured DGM in the equatorial and South Atlantic Ocean. The average concentration measured was $130 \pm 80 \mathrm{pg} \mathrm{L}^{-1}$ and the flux estimated was $15.9 \pm 10.8 \mathrm{ng} \mathrm{m}^{-2}$ hour $^{-1}$. In 1996, higher DGM concentrations were measured by Mason and Sullivan [99] in the equatorial and South Atlantic Ocean than those in the North and consequently the estimated flux was higher. It is suggested that the concentrations reflect a net accumulation of $\mathrm{Hg}(0)$ in the surface water. The flux was extrapolated to an annual flux of $700 \mathrm{ng} \mathrm{m}^{-2}$ year $^{-1}$, a value that could not balance the atmospheric input, therefore, the DGM cycling in the surface waters was not in balance with the atmospheric input [96]. Measurements of DGM in the Pacific waters were first made across the equator (Kim and Fitzgerald, 1988; Fitzgerald, 1995). DGM varied from 10 to $27 \mathrm{pg} \mathrm{L}$, and wa- $^{-1}$ ters were saturated relative to the atmosphere. In contrast, lower concentrations have been observed in the North Pacific. Measurements of DGM were also carried out in the equatorial Pacific Ocean during a cruise in 1990/91 [100,101]. The estimated evasion rates ranged between 12 and $230 \mathrm{ng} \mathrm{m}^{-2} \mathrm{day}^{-1}$, exceeding the rate of atmospheric deposition of $16 \mathrm{ng} \mathrm{m}^{-2} \mathrm{day}^{-1}$ for the region [102], therefore, another source of inorganic $\mathrm{Hg}$ entering into the mixed layer is required to maintain mass balance. It has been suggested that equatorial upwelling of $\mathrm{Hg}$ into the thermocline provides this additional $\mathrm{Hg}$ source and this $\mathrm{Hg}$ is supplied to the equatorial thermocline by the southern circulation of $\mathrm{Hg}$ deposited at mid-latitudes [101,102]. From more recent DGM data, collected in May/June 2002 during a cruise in the North Pacific, the evasional flux estimated (based on the average wind speed, surface water temperatures and the gas exchange equation of Wanninkhof [103], is higher in the tropics and particularly during high wind speed events [91]. Measurements of DGM in the Arctic Ocean (Kongsfjorden) in May 2002 show clear diurnal variation with concentrations up to $70 \mathrm{pg} \mathrm{L}^{-1}$ during daytime and 12 pg L ${ }^{-1}$ during the night time [104]. All waters were found to be saturated with respect to $\mathrm{Hg}$ with an evasion rate between 0.1 and $7 \mathrm{ng} \mathrm{m}^{-2}$ hour ${ }^{-1}$; the major findings were that the outgoing $\mathrm{Hg}$ flux 
was overestimated due to the fjord being partly ice covered, thus, hindering the wave field. St. Louis et al. [105] carried out measurements of DGM at two ice-covered locations off of Ellesmere Island and found average concentrations of $129 \pm 36 \mathrm{pg} \mathrm{L}^{-1}$, which corresponds to super-saturation conditions. The average flux calculated according to Wanninkhof and McGillis [106] was $5.4 \pm 1.2 \mathrm{ng} \mathrm{m}^{-2} \mathrm{hr}^{-1}$ on average; higher fluxes would be expected during $\mathrm{Hg}$ depletion events and ice-breakup and melting in the Spring. Andersson et al. [107] carried out continuous measurements of DGM over the Arctic Ocean. Measurements were carried out in both ice-covered and non ice-covered areas, and the DGM concentration increased up to $80 \%$ between non-ice-covered and ice-covered areas. During the transit through ice-covered areas, enhanced TGM concentrations were observed which were expected to be higher when the ship breaks the ice layer. $\mathrm{An} \mathrm{Hg}(0)$ evasion flux of $98 \mathrm{ng} \mathrm{m}^{-2}$ hour $^{-1}$ was estimated. During summer 2005 (July - September), a cruise was performed over the Atlantic and Arctic Oceans from $60^{\circ}$ to $90^{\circ} \mathrm{N}$ [108]. The results reported by Sommar et al. [108] have highlighted that higher $\mathrm{TGM} / \mathrm{Hg}(0)$ concentrations were observed during Arctic summer over the ice-capped sea. However, a rapid increase of $\mathrm{TGM} / \mathrm{Hg}(0)$ in air and surface water were observed when the Swedish icebreaker Oden went from the North Atlantic into the ice-covered waters of the Canadian Arctic archipelago. Higher $\mathrm{Hg}(0)$ levels were, in fact, obtained along the sea-ice route $\left(1.81 \pm 0.43 \mathrm{ng} \mathrm{m}^{-3}\right)$ compared to those observed in the MBL over ice-free oceanic waters $\left(1.55 \pm 0.21 \mathrm{ng} \mathrm{m}^{-3}\right)$.

\subsection{Hg measurements and air/water exchange over European seas}

\subsubsection{Mediterranean}

An in-depth investigation was carried out from 2000 to 2007 by several research groups in the framework of the MED-OCEANOR project $[24,87,109,110]$ to quantify and possibly explain spatial and temporal patterns of $\mathrm{Hg}$ species concentrations in air, surface and deep water samples, and gaseous $\mathrm{Hg}$ exchange rates at the air-water interface over the Mediterranean Sea [24,87,89,109,111-113]. The sampling campaigns were performed during different seasons and covered both the western and eastern sectors of the Mediterranean basin. A summary of the overwater $\mathrm{Hg}$ species observed during the Mediterranean cruises can be found in Table 4. Observations of the $\mathrm{Hg}$ evasion by Ferrara et al. [3] over the Tyrrhenian Sea during 1998 showed a typical daily trend suggesting that solar radiation is one of the major driving factors affecting the release of $\mathrm{Hg}(0)$ from surface waters. In addition, a seasonal trend was also observed, with minimum values during the winter period and maximum values during the summer, probably due to the higher water temperature that may have facilitated biotic and abiotic processes involving $\mathrm{Hg}$ in the water column. The average $\mathrm{Hg}$ evasion value estimated for the western Mediterranean Sea was lower than the eastern sector, probably due to the higher mean degree of $\mathrm{Hg}(0)$ saturation in the east compared to the west [112]. Past or present tectonic activity may contribute to the high DGM concentrations found in these areas, enhancing higher $\mathrm{Hg}$ evasions from the seawater [112]. The $\operatorname{Hg}(0)$ evasion reported by Gårdfeldt et al. [111] from the western Mediterranean and the Tyrrhenian Sea is of the same order of magnitude as that estimated by both Ferrara et al. [3] and Cossa et al. [114]. DGM data combined with a gas-exchange model [103] suggested that about 66 tonnes of $\mathrm{Hg}(0)$ are released into the atmosphere from the Mediterranean Sea during the summer. This emission estimate is comparable with the amount ofHg emitted from stationary combustion facilities in Europe [57].

\subsubsection{North sea}

Only a few studies to determine $\mathrm{Hg}$ speciation in the North Sea at offshore and coastal stations, including DGM surface water measurement flux, have been performed [115,116]. DGM concentrations at offshore sites observed by Coquery and Cossa [115] ranged from the detection limit to $70 \mathrm{pg} \mathrm{L}^{-1}$, however, the average DGM concentration for the entire study was $52 \pm 22 \mathrm{pg} \mathrm{L}^{-1}$. Most water samples were super-saturated with $\mathrm{Hg}$ giving a net evasion from the sea surface of $0.9-1.8 \mathrm{ng} \mathrm{m}^{-2}$ hour $^{-1}$. The DGM concentration at the off-shore station was $12 \mathrm{pg} \mathrm{L}^{-1}$ [116], which corresponds to an average net evasion of $0.5 \mathrm{ng} \mathrm{m}^{-2}$ hour $^{-1}$, a value comparable to estimated deposition rates. 


\subsubsection{Baltic sea}

Six expeditions have been carried out in the Baltic Sea. Wangberg et al. [117] conducted two of these in summer 1997 and winter 1998 in the southern area. Higher flux $\left(1.6 \mathrm{ng} \mathrm{m}^{-2}\right.$ hour $\left.^{-1}\right)$, calculated using the Wanninkhof [103] model was estimated for the summer, whereas the winter estimate was much lower $\left(0.8 \mathrm{ng} \mathrm{m}^{-2}\right.$ hour $\left.^{-1}\right)$. In 2006, Kuss and Schneider [118] carried out continuous measurements in the southern Baltic Sea during all seasons. The lowest DGM concentrations were measured during winter and autumn (10-17 $\mathrm{pg} \mathrm{L}^{-1}$ and 11-14 $\mathrm{pg} \mathrm{L}^{-1}$, respectively), whereas the highest concentrations were observed during summer (ranging between 19-32 $\mathrm{pg} \mathrm{L}^{-1}$ ) and spring (between 15$20 \mathrm{pg} \mathrm{L}^{-1}$ ). The lowest flux, calculated using the Weiss et al. [119] model, was estimated to occur during the winter season (from -0.2 to $0.2 \mathrm{ng} \mathrm{m}^{-2}$ hour $^{-1}$ ), whereas the highest was in the summer (between 3.1 and $6.2 \mathrm{ng} \mathrm{m}^{-2}$ hour $^{-1}$ ). During the spring and autumn expeditions, fluxes were ranging between 1.0-2.1 and $0.8-2.1 \mathrm{ng} \mathrm{m}^{-2}$ hour $^{-1}$, respectively. On the basis of estimated flux evasion and deposition rates, mass balance was not achieved for the Baltic Sea suggesting that key sources, primary and secondary, have not been accounted for.

\subsection{Mercury measurements in North and South America}

Long-term monitoring of atmospheric $\mathrm{Hg}$ with high time resolution started at Alert, Canada in January 1995, which was the first milestone in the development and set up of the Canadian Atmospheric Mercury Network (CAMNet) (CAMNet, www.msc.ec.gc.ca/arqp/camnet e.cfm) established in 1996. Wet deposition measured at the CAMNet sites are part of the Mercury Deposition Network (MDN, now AMNet), which includes sites in the United States and Canada (http://nadp.sws.uiuc.edu/mdn/). A statistically significant decreasing trend for TGM concentrations at several rural CAMNet sites was seen between 1995 and 2005. This is in good agreement with the overall trend in total Hg concentrations in precipitation observed within the comparable NADP-MDN sites, indicating that these changes are most likely driven by local or regional changes in $\mathrm{Hg}$ emissions. While SOPs are well established in wet deposition existing networks, SOPs to routinely measure dry deposition fluxes are still under development. TGM concentrations at all the CAMNet sites were similar to or slightly lower than those observed at European background sites. More recently, some sites within CAMNet have been measuring atmospheric $\mathrm{Hg}$ species concentrations in addition to TGM. The spatial pattern of $\mathrm{Hg}$ concentrations observed in wet deposition samples at some MDN sites are not well correlated with the spatial distribution of known $\mathrm{Hg}$ sources. There were, in particular, low $\mathrm{Hg}$ concentrations in wet deposition samples collected close to coal-fired power plants in Pennsylvania and Ohio and high values at locations with fewer $\mathrm{Hg}$ sources (i.e., Florida). This confirms that removal processes are important in determining $\mathrm{Hg}$ deposition patterns (oxidation/scavenging) with changing meteorological conditions. The MDN is essential for understanding the spatial and temporal patterns of $\mathrm{Hg}$ in wet deposition, but without, at least, TGM and speciated $\mathrm{Hg}$ measurements in conjunction with precipitation measurements, little can be understood about the processes responsible for enhanced $\mathrm{Hg}$ deposition fluxes and temporal changes of $\mathrm{Hg}$ concentrations in wet deposition samples. More recently, some sites within CAMNet have been measuring atmospheric $\mathrm{Hg}$ species concentrations in addition to TGM. Even though $\mathrm{Hg}(\mathrm{II})$ and $\mathrm{Hg}(\mathrm{P})$ constitute a relatively small portion of TGM in air $(0.2$ to $1.4 \%)$, an evaluation of their concentrations in the atmosphere is essential to better understand the $\mathrm{Hg}$ cycle. Continuous measurements of $\mathrm{Hg}(\mathrm{II})$ and $\mathrm{Hg}(\mathrm{P})$ have been made in Quebec, Nova Scotia and Ontario. At St. Anicet near Montreal, Poissant et al. [120] reported $\mathrm{Hg}(\mathrm{II})$ and $\mathrm{Hg}(\mathrm{P})$ values $\left(3 \pm 11 \mathrm{pg} \mathrm{m}^{-3}\right.$ and $26 \pm 54 \mathrm{pg} \mathrm{m}^{-3}$, respectively) similar to those found by Han et al. [121] at Point Petre ( $\mathrm{Hg}(\mathrm{II}): 5 \pm 5 \mathrm{pg} \mathrm{m}^{-3}$ and $\mathrm{Hg}(\mathrm{P})$ : $6 \pm 7 \mathrm{pg} \mathrm{m}^{-3}$ ) and at Sterling on the south shore of Lake Ontario ( $\left.\mathrm{Hg}(\mathrm{II}): 6 \pm 11 \mathrm{pg} \mathrm{m}^{-3}\right)$. Additional continuous measurements of $\mathrm{Hg}(\mathrm{II})$ and $\mathrm{Hg}(\mathrm{P})$ are needed to fully assess the seasonality of these species. Relatively few observations of atmospheric $\mathrm{Hg}$ have been performed in South America, most of them have been carried out near to, or downwind of major emission sources (i.e., mining or industrial facilities, biomass fires). All currently South American observations show $\mathrm{Hg}(0)$ concentrations substantially greater than the accepted global background level. TGM concentrations observed in rural areas of Brazil, near several tributaries of the Amazon river and urban areas (Rio de Janero, Manaus and Brasilia) were up to $10 \mathrm{ng} \mathrm{m}^{-3}$, whereas adjacent to mining areas concentrations were found to be 
up to $16 \mathrm{ng} \mathrm{m}^{-3}$ [122]. Higueras et al. [123] observed very high TGM concentrations near historical mining regions in the Coquimbo region of Northern Chile, reaching extremely high TGM values, up to $100 \mu \mathrm{g} \mathrm{m}^{-3}$ at some gold recovery operations. Fostier and Michelazzo [124] performed TGM measurements at two sites in Sao Paulo State, Brazil, near an industrial area. An average TGM concentration up to global background $\left(7.0 \mathrm{ng} \mathrm{m}^{-3}\right)$ was observed at both sites due to a wide array of industrial sources in the area. Higher TGM concentrations (mean $15.0 \mathrm{ng} \mathrm{m}^{-3}$ ) were also found by Amouroux et al. [125] at several sites in French Guiana strongly influenced by mining activities along with illegal gold mining. It is clear that past and current gold mining activities in South America represent a large source of $\mathrm{Hg}$ entering into the atmosphere. While emissions of $\mathrm{Hg}$ from gold mining in South America are clearly a substantial source to the global atmosphere, there is a significant uncertainty in the current estimate. TGM concentrations have been performed by De La Rosa et al. [126] during shortterm sampling campaigns at 4 sites in 2002 (two urban/industrial cities, Mexico City and Zacatecas, and two rural/remote sities, Puerto Angel and Huejutla). High variability in TGM levels were found between these sites suggesting a strong influence of local sources. In particular, at Zacatecas, though it is a smaller semi-urban centre compared to Mexico City, but with a history of gold and silver mining activities, the mean $\mathrm{Hg}$ values were very high at $71.7 \mathrm{ng} \mathrm{m}^{-3}$. At Mexico City, mean TGM values were found to be $34 \mathrm{ng} \mathrm{m}^{-3}$, whereas at the two rural/remote sites mean TGM concentrations were close to hemispheric background concentrations (1.46 and $\left.1.32 \mathrm{ng} \mathrm{m}^{-3}\right)$.

\subsection{Mercury measurements in Asia}

Table reports a statistical summary of the mean concentrations of atmospheric $\mathrm{Hg}$ determined from a number of monitoring sites located in East Asian countries. TGM monitoring data for the Korean GAWstation (An-Myun Island) have been published by Nguyen et al. [127]. Measurements were routinely recorded between December 2004 and April 2006. The mean TGM concentration was 4.61 \pm $2.21 \mathrm{ng} \mathrm{m}^{-3}$ with a range of $0.10-25.4 \mathrm{ng} \mathrm{m}^{-3}$. Analysis of the seasonal patterns indicated TGM concentration levels generally peaked in spring, while reaching a minimum in summer. Nguyen et al. [127] concluded that $\mathrm{Hg}$ concentration levels at An-Myun Island over certain periods of time can be greatly affected by the combined effects of various local source processes and meteorological conditions favourable for major air mass transport phenomenon (i.e., Asian Dust storms). TGM concentrations measurements were also carried out by Fu et al. [128] at Moxi base station of the Gongga alpine ecosystem observation and experiment station of the Chinese academy of sciences (CAS) which belongs to the Chinese ecosystem research network (CERN). TGM concentrations ranged between 0.52 and $21.03 \mathrm{ng} \mathrm{m}^{-3}$ from May 2005 to June 2006 with a geometric mean of $3.98 \mathrm{ng} \mathrm{m}^{-3}$. Seasonal TGM patterns correlated with meteorological parameters have highlighted that wind from the southeastern direction carried more $\mathrm{Hg}$ than other directions, suggesting that anthropogenic sources, in particular, local zinc smelting activities and fuel combustion, played a predominant role in the increase of TGM concentrations in this area. Similar TGM concentrations have been also recorded by Wan et al. [129] during the same period at Changbai Mountain, a remote area in northeastern China. An annual arithmetic mean of $3.58 \pm 1.78 \mathrm{ng} \mathrm{m}^{-3}$ was observed which is significantly higher than values obtained in remote areas of Europe and North America. Comparable results have also been observed from April 2006 to June 2007 in the Mt. Gongga area (Sichuan province, PR China) with an annual TGM geometric mean of $3.90 \pm 1.20 \mathrm{ng} \mathrm{m}^{-3}$ [130]. In order to highlight the spatial variation of TGM levels, Fu et al. [130] reported geometric mean TGM concentrations, ranging from 1.60 to $20.1 \mathrm{ng} \mathrm{m}^{-3}$, using data collected during the warm season at 14 representative sampling sites. In this study, urbanized areas showed the highest TGM values $\left(7.76 \pm 4.57\right.$ to $\left.20.1 \pm 15.1 \mathrm{ng} \mathrm{m}^{-3}\right)$, while TGM concentrations for one town area were $4.61 \pm 1.15 \mathrm{ng} \mathrm{m}^{-3}$, for four village areas the values ranged between $3.26 \pm 0.63$ and $8.45 \pm 3.06 \mathrm{ng} \mathrm{m}^{-3}$ and for six remote regions between $1.60 \pm 0.43$ and $3.41 \pm 1.26 \mathrm{ng} \mathrm{m}^{-3}$. The authors suggested that industrial activities were an important source of atmospheric $\mathrm{Hg}$ and played an important role in the regional TGM distribution. Domestic coal and biomass combustion for residential heating were significant TGM sources in densely populated areas. High TGM concentrations compared to global background values were observed at the summit of Mt. Leigong in South China from May 2008 to May 2009 [131] with TGM concentrations averaging $2.80 \pm 1.51 \mathrm{ng} \mathrm{m}^{-3}$, 
these values are, however, much lower than semi-rural and industrial/urban areas, indicating significant emissions of $\mathrm{Hg}$ in central, south and southwest China. Feng et al. [132] have reported TGM concentration data for Guiyang city in 2001 with a mean value of $8.40 \mathrm{ng} \mathrm{m}^{-3}$ on the basis of one year of observations (from November 2001 to November 2002). The average TGM concentration in ambient air observed in Guiyang in 1996 and 1999 was $11 \mathrm{ng} \mathrm{m}^{-3}$ and $13 \mathrm{ng} \mathrm{m}^{-3}$, respectively [132]. The authors concluded that TGM concentrations in Guiyang are significantly elevated compared to the continental global background values and that coal combustion from both industrial and domestic use is probably the primary atmospheric source. Similar data were obtained earlier ([133] during 4 measurement campaigns in 2000 and 2001 in Guiyang. Significant Hg emissions from anthropogenic sources resulted in high levels of atmospheric $\mathrm{Hg}$ also in Guizhou [134]. $\mathrm{Hg}$ species as well as hazardous heavy metals in particles and in precipitation have been continuously measured from 2007 at Cape Hedo Atmosphere and Aerosol Monitoring Station (CHAAMS) located on the north end of the island of Okinawa, Japan. This monitoring station has been used for many years to study the outflow of pollution from China and East Asia [39]. Monthly mean concentrations of $\mathrm{Hg}(0)$ from October 2007 to January 2008 (UNEP/ABC (Atmospheric Brown Clouds) project) were approximately 1.3 to $1.7 \mathrm{ng} \mathrm{m}^{-3}$, which were slightly lower than the spring observation in $2004\left(2.04 \mathrm{ng} \mathrm{m}^{-3}\right)$ [39].

\subsection{Mercury measurements in Africa}

Observations from Cape Point (South Africa) constitute the only long-term dataset of atmospheric TGM in the Southern Hemisphere. The monitoring of TGM was established at the Cape Point Global Atmospheric Watch (GAW) station in September 1995. Baker et al. [97] presented data of atmospheric $\mathrm{Hg}$ covering the period from the start of the measurements (September 1995) until June 1999. Atmospheric $\mathrm{Hg}$ concentrations were found to be fairly homogeneous over time ranging between $1.2-1.4 \mathrm{ng} \mathrm{m}^{-3}$. Whilst no significant diurnal variation was detectable, a slight seasonal variation with a TGM minimum in springtime and maximum in summertime was observed. The most prominent feature of the highly resolved TGM data is the frequent occurrence of events with almost complete mercury depletion which has so far not been observed at any other non-polar stations [28].

\subsection{Mercury measurements at high altitude locations (including aircraftmeasurements)}

In an effort to understand the relative importance of anthropogenic and natural emissions of airborne $\mathrm{Hg}$, several studies have attempted to calculate $\mathrm{Hg}$ fluxes from source regions. This could be done additionally by correlating $\mathrm{Hg}$ enhancements in plumes to other tracers whose emissions are better known (i.e., CO). Most air quality monitoring networks rely entirely upon ground-based sites that sample within the boundary layer. Addressing global air quality problems such as $\mathrm{Hg}$ contamination, however, requires observations made at higher altitudes in order to intercept intercontinental transport phenomena. Studies have shown that transport of pollution (including $\mathrm{Hg}$ ) between Asia and the United States occurs primarily through the middle and upper troposphere, and because of the highly episodic nature of this transport, there can be significant in-homogeneity in the air masses reaching the continental United States [39]. Thus, sites that sample only air masses within the boundary layer would not allow a quantitative determination of long-range pollutant fluxes. Ebinghaus et al. [54] observed enhanced $\mathrm{CO}$ and TGM on two CARIBIC (Civil Aircraft for Regular Investigation of the Atmosphere Based on an Instrumented Container) flights between Sao Paolo and Santiago de Chile in 2005. The measured TGM/CO ratio on these two flights, $\left(1.2 \times 10^{-7}\right.$ and $2.4 \times 10^{-7} \mathrm{~mole} / \mathrm{mole}$, respectively) were similar to those found for biomass burning plumes. From these ratios, global emissions of TGM from biomass burning were estimated to be in the range of $210-750 \mathrm{Mg}_{\text {year }}^{-1}$. While observations with aircraft provide detailed information about $\mathrm{Hg}$ in the upper troposphere/lower stratosphere [135-137] and vertical profiles in the troposphere, they certainly do not provide long-term trends. Therefore, the use of intercontinental mountain-top monitoring sites, that are frequently in the free-troposphere (i.e., Mauna Loa, Hawaii) are essential in understanding the transport of $\mathrm{Hg}$ and other air pollutants [138]. Currently, there are a number of high elevation sites including Mt. Bachelor in the western USA [139], Mauna Loa in Hawaii [140], Wank Mt. in Germany [141], and the Lulin station in Taiwan [142]. In two 
recent studies, TGM and CO were measured in 22 pollution transport "events" at Mt. Bachelor ( $2800 \mathrm{~m}$ asl) between 2004 and 2005 [138]. East Asian outflow events yielded a TGM/CO enhancement ratio of about $0.005 \mathrm{ng} \mathrm{m}^{-3} \mathrm{ppbv}^{-1}$, whereas plumes from western USA anthropogenic sources and from biomass burning in the Pacific Northwest and Alaska gave a ratio of about $0.001 \mathrm{ng} \mathrm{m}^{-3} \mathrm{ppbv}^{-1}$. The TGM/CO ratio is therefore, an important distinguishing feature to identify Asian long-range transport patterns. Scaling these ratios with estimated emissions of $\mathrm{CO}$ from China and global biomass burning, an emission of $620 \mathrm{Mg} \mathrm{year}^{-1}$ is calculated for total $\mathrm{Hg}$ emissions from Chinese anthropogenic sources and $670 \mathrm{Mg}$ year ${ }^{-1}$ for global biomass burning. The $\mathrm{Hg}(0) / \mathrm{CO}$ molar enhancement ratio was observed in pollution plumes at Cape Hedo Station, Okinawa, Japan which is nearly twice the expected ratio based on emissions estimates from China [39]. These plumes originated from the industrialized region of eastern China and produced a similar ratio to those observed at Mt. Bachelor, highlighting the discrepancy between the results observed and the recent Chinese emission inventories. These findings are probably due to large natural sources of $\mathrm{Hg}$ not accounted for and/or underestimated $\mathrm{Hg}$ emissions. The first reported data on $\mathrm{Hg}$ species performed at high altitude are from Mauna Loa, (Hawaii Monitoring Site, [140] and Mt. Bachelor, (Oregon, USA, [143]. Both sites revealed elevated $\mathrm{Hg}(\mathrm{II})$ values in the free troposphere (about $350 \mathrm{pg} \mathrm{m}^{-3}$ at Mauna Loa and about $600 \mathrm{pg} \mathrm{m}^{-3}$ at Mt. Bachelor), reaching those of the most polluted urban environments. Several high $\mathrm{Hg}$ (II) events, generally accompanied by a decrease in $\mathrm{Hg}(0)$, have been observed under meteorological conditions clearly marked by dry (free tropospheric) air at night [143]. Swartzendruber et al. [143] observed that the mean $\mathrm{Hg}$ (II) concentration at night was $60 \mathrm{pg} \mathrm{m}^{-3}$, whereas the daytime mean value was $39 \mathrm{pg} \mathrm{m}^{-3}$ in contrast to other studies showing an $\mathrm{Hg}(\mathrm{II})$ maximum at solar noon. $\mathrm{Hg}(\mathrm{P})$ concentrations were equivalent for day and night (about $4.4 \mathrm{pg} \mathrm{m}^{-3}$ ). This implies that $\mathrm{Hg}$ (II) formed in situ was unable to condense to particles under these dry air conditions. Both these studies $([140,143]$ found very similar observations pointing out that the high $\mathrm{Hg}$ (II) concentrations observed, first in Hawaii and later in Oregon were due to atmospheric oxidation and not related to pollution events. Similar results have been obtained in Colorado at the Storm Peak Laboratory high altitude research station ( $3220 \mathrm{~m}$ asl) by Faïn et al. [7]. They showed a very regular occurrence of high $\mathrm{Hg}(\mathrm{II})$ levels in dry tropospheric air that was not related to pollution events, but highlighted signs of atmospheric oxidation, likely in the free troposphere, and possibly over the Pacific Ocean. These observations provide evidence that the free tropospheric pool of $\mathrm{Hg}$ is enriched with $\mathrm{Hg}$ (II) compared to the boundary layer where high $\mathrm{Hg}$ (II) levels are mainly related to local and regional pollution.

\subsection{Mercury measurements in Arctic and Antarctic Regions}

Polar Regions used to be considered pristine environments. Indeed, the Arctic is relatively far from industrial sites located in the Northern Hemisphere and is less populated than other parts of the world. Antarctica is even less populated and less impacted by anthropogenic activities, except on a local scale by the activities of few scientific stations. However, due to a combination of long-range transport associated with a specific climatology, the Arctic and, to a lesser extent Antarctic, are affected on a large scale by pollutants originating from the mid-latitudes of their respective hemispheres. The substantially different geographical distribution of landmasses around both poles influences the $\mathrm{Hg}(0)$ annual mean concentration observed in the Arctic $\left(1.6 \mathrm{ng} \mathrm{m}^{-3}\right)$ and Antarctica $\left(1.0 \mathrm{ng} \mathrm{m}^{-3}\right)$. Atmospheric mercury has unique characteristics that include long-range transport to Polar Regions and its transformation to more toxic and water-soluble compounds that may potentially become bioavailable. These chemical-physical properties have placed mercury on the priority list of an increasing number of International, European and National conventions and agreements, aimed at the protection of the ecosystems (i.e. GEO, UNEP, AMAP, UNECE, HELCOM, OSPAR). This interest, in turn, stimulates a significant amount of research including measurements of gaseous elemental mercury reaction rate constant with atmospheric oxidants, experimental and modeling studies in order to understand the cycling of mercury in Polar Regions, and its impact to these ecosystems. Special attention in terms of contamination is paid to the consequences of the springtime phenomena, referred to as "Atmospheric Mercury Depletion Events" (AMDEs). Research literature [16, 144-149] provide a comprehensive assessment of the state of $\mathrm{Hg}$ in the context of AMDEs in Polar Regions since 1995. First identified at Alert in the Canadian High Arctic [150], AMDEs occur during the 3-month period 
following polar sunrise. During these events, $\mathrm{Hg}(0)$ may be converted to $\mathrm{Hg}(\mathrm{II})$ and/or $\mathrm{Hg}(\mathrm{P})$, that deposit quickly into the snow/ice pack increasing the mercury deposition fluxes considerably. Springtime AMDEs have also been observed in Antarctica [16]. AMDEs occur at the same time as tropospheric ozone depletion events (ODEs) suggesting that both species were removed by similar chemical mechanisms involving reactive halogen species (i.e., $\mathrm{Br}$ and $\mathrm{BrO}$ ) across open waters and polynas. $\mathrm{BrO}$ is one of the species observed during ODEs and, therefore, often used as an indicator for such events. Several experiments have been performed at different Arctic and sub-Arctic locations (Ny-Ålesund, Svalbard 78 $54^{\prime} N$ 11 ${ }^{\circ} 53^{\prime}$ E [145, 146, 151, 152]; Pt. Barrow, Alaska 71 ${ }^{\circ} 19^{\prime} \mathrm{N} 156^{\circ} 37^{\prime} \mathrm{W}$

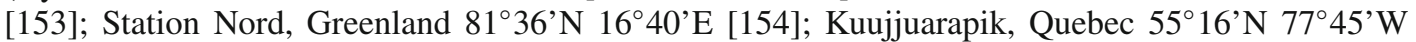
[155]; Amderma, Russia $69^{\circ} 45^{\prime} \mathrm{N} 61^{\circ} 40^{\prime} \mathrm{E}$ [156]. While the tropospheric reactivity of mercury in the Arctic is more and more documented only a few attempts were made to study the $\mathrm{Hg}$ cycle in Antarctica. AMDEs were observed in Coastal Antarctica after polar sunrise at Neumayer and Terra Nova Bay $[144,157]$. The study of the $\mathrm{Hg}$ cycling in Antarctica is first necessary to understand and follow the extent of the contamination within these ecosystems. Mercury concentrations in biota of some Arctic areas are known to have increased with time [158] and to be rather high. In Antarctica, available data on $\mathrm{Hg}$ concentrations in water, sediments, phytoplankton, macroalgae, krill and several species of benthic invertebrates compiled by Bargagli et al. [159] indicate that there is no enhanced bioavailability of $\mathrm{Hg}$ in the Southern Ocean food web. However, recent studies showed an enhanced $\mathrm{Hg}$ bioaccumulation in terrestrial ecosystem samples collected close to Terra Nova Bay [160], suggesting that local deposition events of $\mathrm{Hg}$ may impact these ecosystems. Mercury measurements performed at different locations within the Arctic and Antarctic regions are reported in Table 5, which is from Dommergue et al. [149] The first extended baseline data for the concentration and speciation of atmospheric $\mathrm{Hg}$ in Antarctica were reported by De Mora et al. [161]. The measurements reported by Ebinghaus et al. [16] comprise of the first annual time series of ground-level TGM concentrations in Antarctica to investigate the occurrence of possible AMDEs in south polar regions. The study also provides high-resolution data that can be compared with existing datasets of AMDEs in the Arctic, and reveals similarities. The TGM series measured at Neumayer showed several $\mathrm{Hg}$ depletion events during Antarctic springtime (between August and November 2000); TGM and $\mathrm{O}_{3}$ were strongly and positively correlated as seen in the Arctic boundary layer after polar sunrise. Simultaneous measurements of $\mathrm{Hg}(0)$ and $\mathrm{Hg}$ (II) were performed at Terra Nova Bay from November 2000 to January 2001. ODEs and MDEs were not observed throughout this period at Terra Nova Bay, however, $\mathrm{Hg}$ (II) concentrations during the measurement period were surprisingly high and comparable with those at sites directly influenced by significant anthropogenic $\mathrm{Hg}$ sources suggesting that there are specific mechanisms and/or characteristics of polar environments that at certain times, and apparently in the presence of surface snow, are extremely favourable to the production of $\mathrm{Hg}$ (II). Comparable $\mathrm{Hg}$ (II) results have been reported by Temme et al. [147] at Neumayer during Antarctic summertime suggesting that the snow-pack is directly involved in maintaining high $\mathrm{Hg}(\mathrm{II})$ concentrations. Long-term measurements of $\mathrm{Hg}(0)$ and other atmospheric $\mathrm{Hg}$ species in the Polar Regions are very limited and need to be increased. These types of measurements can yield critical information for a better understanding of the processes involved in the $\mathrm{Hg}$ cycle in the polar atmosphere and the mechanisms characterizing the deposition of this pollutant to this fragile environment.

\section{Chemical and physical processes affecting atmospheric mercury}

Mercury exists in two oxidation states in the atmosphere, $\mathrm{Hg}(0)$ and $\mathrm{Hg}(\mathrm{II})$. Both the elemental and oxidised states of mercury are found in the gas phase, associated with particulate matter, and in the atmospheric aqueous phase, both in clouds and rain, and in deliquesced aerosols. The two forms have very different physical properties and this ultimately decides their fate, elemental $\mathrm{Hg}$ is less reactive, more volatile and most importantly less soluble than oxidised $\mathrm{Hg}$. The most important aspect in determining the fate and transport of $\mathrm{Hg}$ in the atmosphere is therefore its redox chemistry. Oxidised $\mathrm{Hg}$ is much more likely to deposit and remain in other ecosystem compartments than $\operatorname{Hg}(0)$ and is therefore important in the $\mathrm{Hg}$ biogeochemical cycle. Elemental $\mathrm{Hg}$ on the other hand, being less likely to deposit or be scavenged by cloud droplets, is the form of $\mathrm{Hg}$ responsible for its long range 


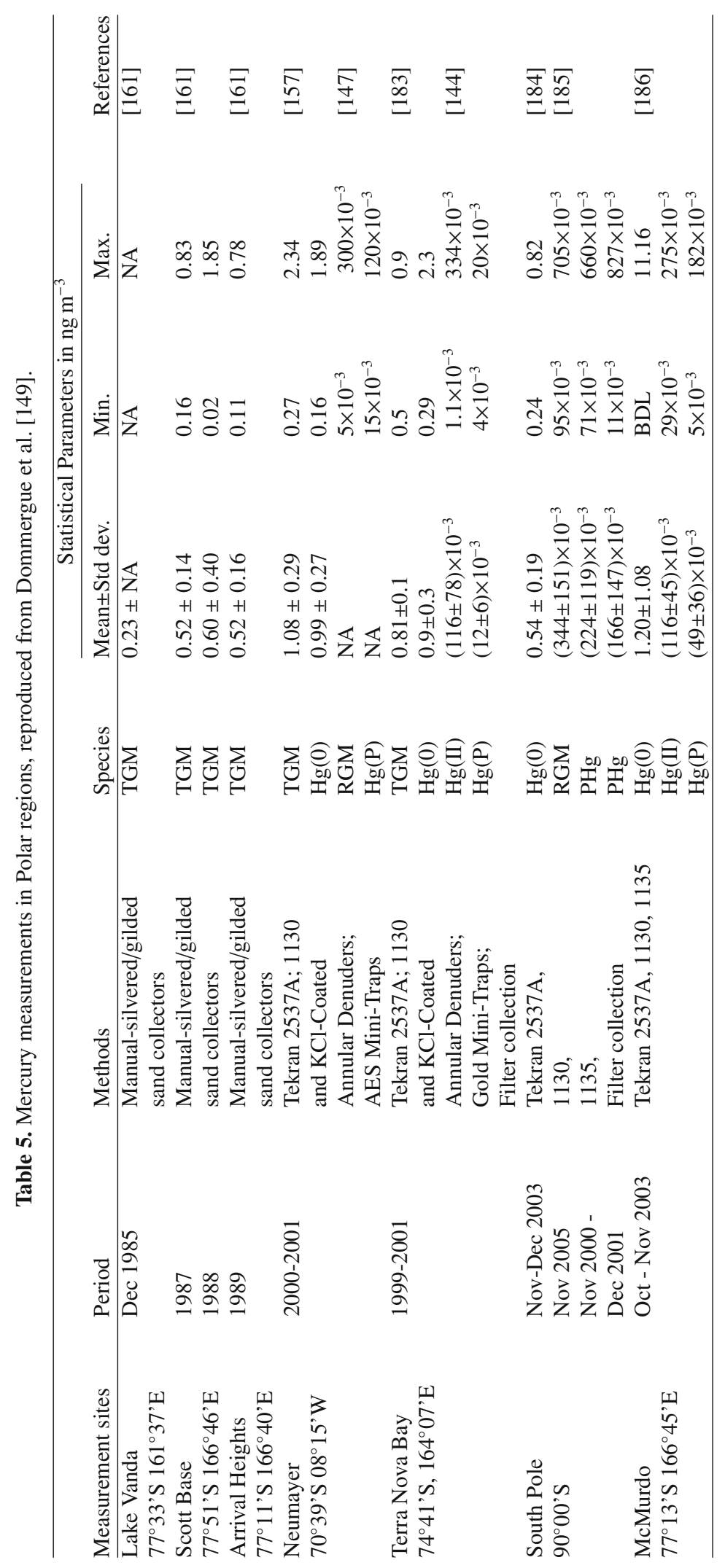


atmospheric transport. Mercury can be oxidised and reduced in the gas phase and the aqueous phase. It can also undergo reaction at air/snow and air/water surfaces air/solid although most of the studies of these heterogeneous have been at terrestrial or marine interfaces, or under conditions representative of flue gases in the latter instance. It is not clear whether the same reactions seen at the surface would occur on a droplet or snowflake in the atmosphere. This discussion will be limited therefore primarily to homogeneous reactions. The atmospheric oxidants generally considered to be the most important in terms of $\mathrm{Hg}$ oxidation are $\mathrm{O}_{3}, \mathrm{OH}$ and $\mathrm{Br}$. Experimental determinations of the reaction rate constants for these oxidants at conditions similar to those of the atmosphere (troposphere in particular) have proved to be difficult. There is still some debate over whether some of them, $\mathrm{O}_{3}$ and $\mathrm{OH}$, actually oxidise $\mathrm{Hg}$ at all in the atmosphere, [162] and thus there has been some questioning of the experimental techniques used in the determination of the reaction rate constants [30]. A detailed review of the methods and a comparison of the results obtained from the various laboratory, theoretical and field determination of $\mathrm{Hg}$ reaction kinetics can be found in Hynes et al. and Ariya et al. $[30,163]$. The one reaction which is unanimously accepted is the reaction of $\mathrm{Hg}$ with $\mathrm{Br}$. This reaction is responsible for the $\mathrm{Hg}$ depletion events first observed in the Arctic around polar dawn [150]. The depletion of $\mathrm{Hg}$ occurs at the same time as $\mathrm{O}_{3}$ is destroyed, thereby eliminating both $\mathrm{O}_{3}$ and $\mathrm{OH}$ as potential candidates for the observed decrease in $\mathrm{Hg}(0)$ concentration leaving $\mathrm{Br}$ as the only known candidate. A box modelling study using the observed $\mathrm{O}_{3}$ decrease to constrain the $\mathrm{Br}$ concentration showed that the published rate constants for $\mathrm{Hg}+\mathrm{Br}$, both experimental [164] and theoretical [165], managed to reproduce the observed decrease in $\mathrm{Hg}(0)$ concentration [166]. The reaction of $\mathrm{Hg}$ with $\mathrm{Br}$ has been examined in global and regional modelling contexts, [166-169]. It appears that the reactions of $\mathrm{Hg}$ with $\mathrm{O}_{3}$ and $\mathrm{OH}$ are not necessary to explain a number of the major features of $\mathrm{Hg}(0)$ and $\mathrm{Hg}$ (II) concentration fields in the atmosphere. There is an important caveat to the above statement however. It is possible that reduction reactions are occurring in the gas phase in the atmosphere. Two suggestions have been made in the literature, one is $\mathrm{CO}$, which is known to reduce $\operatorname{solid} \mathrm{Hg}(\mathrm{O})$, [170] although experiments under conditions which resemble those in the atmosphere have not as far as we are aware been performed. The other is $\mathrm{SO}_{2}$, the evidence that this reaction may be taking place comes from modelling studies of power plant plumes and was suggested by Vijayaraghavan et al. [171]. Reduction processes are extremely important in the overall $\mathrm{Hg}$ cycle, it is the reduction of deposited $\mathrm{Hg}$ (II) on land and sea surfaces which permits the re-emission of $\operatorname{Hg}(0)$ and ensures that it is transported all round the globe. Currently the known reduction reactions for atmospheric $\mathrm{Hg}$ occur in the atmospheric aqueous phase. Oxidation also occurs in the aqueous phase, however in comparison to gas phase oxidation it contributes very little to the overall $\mathrm{Hg}$ (II) atmospheric concentration. In the atmospheric aqueous phase $\mathrm{Hg}$ (II) can form coordination complexes with $\mathrm{SO}_{3}^{2-}$, to give $\mathrm{HgSO}_{3}$ and $\mathrm{Hg}\left(\mathrm{SO}_{3}\right)_{2}^{2-}$, the latter is redox stable while the former is not, and $\mathrm{HgSO}_{3}$ can dissociate in the presence of water to give $\mathrm{Hg}(0)+\mathrm{SO}_{4}^{-}+\mathrm{H}^{+}$. The other reduction which has been identified in the laboratory, but whose atmospheric relevance is debated, is the reaction of $\mathrm{Hg}$ (II) with $\mathrm{HO}_{2}$. The reduction to $\mathrm{Hg}(0)$ is a two step process, $\mathrm{Hg}(\mathrm{II})$ reacting with $\mathrm{HO}_{2}$ to give $\mathrm{Hg}(\mathrm{I})$ which is then further reduced by another $\mathrm{HO}_{2}$. The point which some authors have called into question (see Gårdfeldt et al. [172]) is the reduction of $\mathrm{Hg}(\mathrm{I})$, as they assert that $\mathrm{Hg}(\mathrm{I})$ in the presence of dissolved $\mathrm{O}_{2}$ would be extremely rapidly re-oxidised back $\mathrm{Hg}(\mathrm{II})$, thereby competing with the second reduction step and blocking the production of $\mathrm{Hg}(0)$. The lack of certainty over the basic atmospheric chemistry of $\mathrm{Hg}$ leads to uncertainty in the atmospheric modelling of $\mathrm{Hg}$, which in turn produces uncertainties in estimates of $\mathrm{Hg}$ deposition fluxes and limits our ability to determine the possible influences of changes in $\mathrm{Hg}$ emissions or the response of the atmospheric part of the $\mathrm{Hg}$ cycle to climate change forcing.

\subsection{Atmospheric mercury modelling}

A number of modelling approaches are used to model atmospheric mercury processes, they range in scale from very local, using box and one-dimensional models to investigate specific phenomena, to regional models based on air quality models, through to global models used to investigate the longrange transport and deposition of $\mathrm{Hg}$. Recently global models have begun to be coupled with ocean 
models to better understand air/sea interactions in the global $\mathrm{Hg}$ atmospheric cycle. Regional modelling of $\mathrm{Hg}$ emission, transport and chemistry has been the subject of a number of review articles over the last few years [170,173-176], and although they have improved over the years they suffer form limitations in the representation of atmospheric $\mathrm{Hg}$ chemistry, and are plagued by the fact that they are very susceptible to the boundary conditions which are employed. Pongprueksa et al, [170] demonstrated with the CMAQ-Hg model, that the response of the modelled $\mathrm{Hg}$ concentration and deposition to changes in the boundary conditions used was nearly linear $\left(\mathrm{r}^{2}=0.99\right)$ with a $1 \mathrm{ng} \mathrm{m}^{-3}$ increase in $\mathrm{BC} \mathrm{Hg}(0)$ concentration producing an increase of $0.81 \mathrm{ng} \mathrm{m}^{-3}$ in the average $\operatorname{model~} \mathrm{Hg}(0)$ concentration. The response to initial conditions was similar but weaker a $0.14 \mathrm{ng} \mathrm{m}^{-3}$ increase in the average model $\mathrm{Hg}(0)$ concentration for a $1 \mathrm{ng} \mathrm{m}^{-3}$ increase in the initial $\mathrm{Hg}(0)$ condition. For this reason over recent years a lot of effort has been made to improve global $\mathrm{Hg}$ models as it is now clear that they are required to provide the boundary conditions for regional models if the regional model output is to be credible. An overview of most of the models used to simulate global atmospheric $\mathrm{Hg}$ chemistry can be found in the recent Mercury Fate and Transport Report to UNEP (Chapters 17-21), [177]. Most of these models have used the $\mathrm{Hg}+\mathrm{O}_{3} / \mathrm{OH}$ oxidation scheme and the $\mathrm{HO}_{2}$ reduction of $\mathrm{Hg}$ (II) in the aqueous phase as the basis of their atmospheric $\mathrm{Hg}$ scheme up to now. In the last couple of years however the focus of modelling studies has been moving away from this almost "traditional' approach in an attempt to determine the role of $\mathrm{Br}$ in atmospheric $\mathrm{Hg}$ chemistry. These include box modelling studies of the role of the $\mathrm{Hg}+\mathrm{Br}$ in the Arctic [166], and also the Marine Boundary Layer in the Mediterranean [89,169] and the remote Pacific and Atlantic [168]. This new focus also includes an investigation of $\mathrm{Hg}$ chemistry in volcanic plumes using a one-dimensional model, [178], and an investigation into the global free tropospheric lifetime of $\mathrm{Hg}(0)$ atmospheric $\mathrm{Hg}$ against oxidation by $\mathrm{Br}$ [167]. Most recently a global model has been used to investigate the relative merits of the $\mathrm{O}_{3} / \mathrm{OH}$ oxidation scheme in comparison to the $\mathrm{Br}$ oxidation scheme [179]. It appears to the authors that consensus is coming down on the side of Bromine as the major $\mathrm{Hg}$ oxidant in the atmosphere. This will cause a number of problems for modellers because while $\mathrm{O}_{3}$ precursor emission chemistry and $\mathrm{OH}$ production are relatively well known, $\mathrm{Br}$ emission sources are less well characterised and introducing $\mathrm{Br}$ chemistry into current atmospheric chemistry models could prove to difficult. It should be pointed out that while it seems that the question of atmospheric $\mathrm{Hg}$ oxidation may be being resolved, that of atmospheric $\mathrm{Hg}$ reduction does not. Almost all modelling studies suffer from a lack of long term $\mathrm{Hg}$ concentration and flux data with which to compare their output. While some series exist for parts of Europe and North America they are the exception, and the Southern hemisphere in particular has an extremely sparse data set with which models can be compared. This is a situation which given some of the serious uncertainties inherent in current models really does need to be rectified.

\section{Major policy frameworks}

The importance of environmental issues related to mercury released to the atmosphere by major anthropogenic sources, which include, but are not limited to, power plants for energy production and a variety of industrial plants, has gained growing attention for their effects on human health and ecosystems. During the last decade a number of international programs have been initiated with an overall goal to develop a policy framework aiming to control and possibly reduce the use of mercury and its release to the global environment and ultimately its impact on human health and ecosystems. The UNEP Mercury Programme has started, since 2002, a process to assess to what extent contamination by mercury released from anthropogenic and natural sources may affect human health and ecosystems. A number of concerted initiatives have been undertaken at global scale to assess the current state of our knowledge on atmospheric mercury emissions, transport and deposition to and evasion from terrestrial and aquatic ecosystems and to evaluate the relative contributions of natural and anthropogenic sources to the global atmospheric mercury budget. At the beginning of 2005 the Governing Council of the United Nations Environment Programme (UNEP-GC) urged (Decision 23/9 IV), governments, inter-governmental and non-governmental organizations and the private sector to develop and implement partnerships as one approach to reducing the risks to human health and the environment from 
the release of mercury and its compounds improving global understanding of international mercury emission sources, fate and transport. In this framework, the UNEP Global Partnership for Mercury Air Transport and Fate Research (UNEP-MFTP) was started in 2005 aiming to encourage collaborative research activities on different aspects of atmospheric mercury cycling on local to hemispheric and global scales. Recently, as part of the work plan (2009-2011) of the Group on Earth Observations (GEO), the Task 09-02d "Global Monitoring Plan for Atmospheric Mercury" aiming to develop a global observation system for mercury was established. This task supports the achievement of the goals of GEOSS and other on-going international programs (e.g. UNEP Mercury Program) and conventions (i.e., UNECE-LRTAP TF HTAP). Programs such as the World Meteorological Organization's Global Atmosphere Watch (GAW) have made substantial efforts to establish data centres and quality control programs to enhance integration of air quality measurements from different national and regional networks, and to establish observational sites in under-sampled, remote regions around the world. Similarly, the International Global Atmospheric Chemistry project (of the International GeosphereBiosphere Programme) has strongly endorsed the need for international exchange of calibration standards, and has helped coordinate multinational field campaigns to address a variety of important issues related to global air quality. Following the lead of these programs, the incorporation of a well-defined $\mathrm{Hg}$ monitoring component into the existing network of sites would be the most expeditious and efficient approach to realise a global $\mathrm{Hg}$ monitoring network. Close coordination of the global modelling community with the global measurement community would lead to major advances in the global models, and also advance our understanding of $\mathrm{Hg}$ science, while at the same time decreasing the uncertainties in global assessments for $\mathrm{Hg}$ entering aquatic and terrestrial ecosystems.

\section{References}

1. N. Pirrone, G.J. Keeler, J.O. Nriagu, Atmospheric Environment 30(17), 2981 (1996)

2. N. Pirrone, S. Cinnirella, X. Feng, R.B. Finkelman, H.R. Friedli, J. Leaner, R. Mason, A.B. Mukherjee, G. Stracher, D.G. Streets et al., in Mercury Fate and Transport in the Global Atmosphere: Emissions, Measurements and Models, edited by N. Pirrone, R.P. Mason (Springer, 2009), chap. 1, pp. 1-47

3. R. Ferrara, B. Mazzolai, E. Lanzillotta, E. Nucaro, N. Pirrone, The Science of The Total Environment 259(1-3), 183 (2000)

4. R.P. Mason, in Mercury Fate and Transport in the Global Atmosphere: Emissions, Measurements and Models, edited by N. Pirrone, R.P. Mason (Springer, 2009), chap. 7, pp. 173-191

5. E.G. Pacyna, J.M. Pacyna, F. Steenhuisen, S. Wilson, Atmospheric Environment 40(22), 4048 (2006)

6. E. Pacyna, J. Pacyna, K. Sundseth, J. Munthe, K. Kindbom, S. Wilson, F. Steenhuisen, P. Maxson, Atmospheric Environment 44(20), 2487 (2010)

7. X. Faïn, D. Obrist, A.G. Hallar, I. Mccubbin, T. Rahn, Atmospheric Chemistry and Physics 9(20), 8049 (2009)

8. P. Weiss-Penzias, D.A. Jaffe, P. Swartzendruber, J.B. Dennison, D. Chand, W. Hafner, E. Prestbo, Journal Of Geophysical Research - Atmospheres 111(D10), D10304 (2006)

9. S. Lindberg, R. Bullock, R. Ebinghaus, D. Engstrom, X. Feng, W. Fitzgerald, N. Pirrone, E. Prestbo, C. Seigneur, AMBIO: A Journal of the Human Environment 36(1), 19 (2007)

10. D.M. Murphy, P.K. Hudson, D.S. Thomson, P.J. Sheridan, J.C. Wilson, Environmental Science \& Technology 40(10), 3163 (2006)

11. R. Talbot, H. Mao, E. Scheuer, J. Dibb, M. Avery, Geophys. Res. Lett. 34(23), L23804 (2007)

12. N. Pirrone, I. Allegrini, G.J. Keeler, J.O. Nriagu, R. Rossmann, J.A. Robbins, Atmospheric Environment 32(5), 929 (1998)

13. R. Bindler, I. Renberg, P.G. Appleby, N.J. Anderson, N.L. Rose, Environmental Science \& Technology 35(9), 1736 (2001)

14. H. Biester, R. Kilian, C. Franzen, C. Woda, A. Mangini, H.F. Schöler, Earth and Planetary Science Letters 201, 609 (2002)

15. D.G. Streets, Q. Zhang, Y. Wu, Environmental Science \& Technology 43(8), 2983 (2009) 
16. R. Ebinghaus, H.H. Kock, A.M. Coggins, T.G. Spain, S.G. Jennings, C. Temme, Atmospheric Environment 36(34), 5267 (2002)

17. F. Slemr, R. Ebinghaus, P. Simmonds, S. Jennings, Atmospheric Environment 40(36), 6966 (2006)

18. W.F. Fitzgerald, Water, Air, \& Soil Pollution 80(1), 245 (1995)

19. K.H. Kim, R. Ebinghaus, W.H. Schroeder, P. Blanchard, H.H. Kock, A. Steffen, F.A. Froude, M.Y. Kim, S. Hong, J.H. Kim, Journal of Atmospheric Chemistry 50(1), 1 (2005)

20. N. Pirrone, P. Costa, J.M. Pacyna, R. Ferrara, Atmospheric Environment 35(17), 2997 (2001)

21. I. Wängberg, J. Munthe, N. Pirrone, A. Iverfeldt, E. Bahlman, P. Costa, R. Ebinghaus, X. Feng, R. Ferrara, K. Gårdfeldt et al., Atmospheric Environment 35(17), 3019 (2001)

22. I. Wängberg, J. Munthe, D. Amouroux, M. Andersson, V. Fajon, R. Ferrara, K. Gårdfeldt, M. Horvat, Y. Mamane, E. Melamed et al., Environmental Fluid Mechanics 8(2), 101 (2008)

23. J. Munthe, I. Wängberg, N. Pirrone, A. Iverfeldt, R. Ferrara, R. Ebinghaus, X. Feng, K. Gårdfeldt, G. Keeler, E. Lanzillotta et al., Atmospheric Environment 35(17), 3007 (2001)

24. N. Pirrone, M. Wichmann-Fiebig, Atmospheric Environment 37 (Supplement 1), 3 (2003)

25. N. Pirrone, Atmospheric Environment 35(17), 2979 (2001)

26. I.M. Hedgecock, N. Pirrone, Environmental Science \& Technology 38(1), 69 (2004)

27. N. Pirrone, I.M. Hedgecock, F. Sprovieri, Atmosperic Environment 42(36), 8549 (2008)

28. E.G. Brunke, C. Labuschagne, R. Ebinghaus, H.H. Kock, F. Slemr, Atmospheric Chemistry and Physics 10(3), 1121 (2010)

29. F. Sprovieri, N. Pirrone, R.P. Mason, M. Andersson, in Mercury Fate and Transport in the Global Atmosphere: Emissions, Measurements and Models, edited by N. Pirrone, R.P. Mason (Springer, 2009), chap. 11, pp. 323-380

30. A.J. Hynes, D.L. Donohoue, M.E. Goodsite, I.M. Hedgecock, in Mercury Fate and Transport in the Global Atmosphere: Emissions, Measurements and Models, edited by N. Pirrone, R.P. Mason (Springer, 2009), chap. 14, pp. 427-457

31. N.E. Selin, Annual Review of Environment and Resources 34(1), 43 (2009)

32. E.M. Sunderland, R.P. Mason, Global Biogeochem. Cycles 21(4), GB4022 (2007)

33. N.E. Selin, D.J. Jacob, R.M. Yantosca, S. Strode, L. Jaeglé, E.M. Sunderland, Global Biogeochem. Cycles 22, GB2011 (2008)

34. R.P. Mason, G.R. Sheu, Global Biogeochem. Cycles 16(4), 1093 (2002)

35. S.A. Strode, L. Jaeglé, N.E. Selin, D.J. Jacob, R.J. Park, R.M. Yantosca, R.P. Mason, F. Slemr, Global Biogeochem. Cycles 21(1), GB1017 (2007)

36. J.F. Hamilton, G. Allen, N.M. Watson, J.D. Lee, J.E. Saxton, A.C. Lewis, G. Vaughan, K.N. Bower, M.J. Flynn, J. Crosier et al., Journal Of Geophysical Research - Atmospheres 113(D20), D20313 (2008)

37. I. Wängberg, J. Munthe, T. Berg, R. Ebinghaus, H. Kock, C. Temme, E. Bieber, T. Spain, A. Stolk, Atmospheric Environment 41(12), 2612 (2007), ISSN 1352-2310

38. A. Iverfeldt, J. Munthe, C. Brosset, J. Pacyna, Water, Air, \& Soil Pollution 80(1), 227 (1995)

39. D. Jaffe, E. Prestbo, P. Swartzendruber, P. Weiss-Penzias, S. Kato, A. Takami, S. Hatakeyama, Y. Kajii, Atmospheric Environment 39(17), 3029 (2005)

40. C.H. Lamborg, W.F. Fitzgerald, A.W.H. Damman, J.M. Benoit, P.H. Balcom, D.R. Engstrom, Global Biogeochem. Cycles 16(4), 1104 (2002)

41. J. Munthe, R.A.D. Bodaly, B.A. Branfireun, C.T. Driscoll, C.C. Gilmour, R. Harris, M. Horvat, M. Lucotte, O. Malm, AMBIO: A Journal of the Human Environment 36(1), 33 (2007)

42. C.D. Knightes, E.M. Sunderland, M.C. Barber, J.M. Johnston, R.B. Ambrose, Environmental Toxicology and Chemistry 28(4), 881 (2009)

43. D.M. Orihel, M.J. Paterson, P.J. Blanchfield, R.A.D. Bodaly, H. Hintelmann, Environmental Science \& Technology 41(14), 4952 (2007)

44. H. Hintelmann, R. Harris, A. Heyes, J.P. Hurley, C.A. Kelly, D.P. Krabbenhoft, S. Lindberg, J.W.M. Rudd, K.J. Scott, V.L. St. Louis, Environmental Science \& Technology 36(23), 5034 (2002)

45. J.O. Nriagu, J.M. Pacyna, Nature 333(6169), 134 (1988) 
46. J.M. Pacyna, E.G. Pacyna, F. Steenhuisen, S. Wilson, Atmospheric Environment 37 (Supplement 1), 109 (2003)

47. L.D. de Lacerda, Nature 374(6517), 20 (1995)

48. M.M. Veiga, P.A. Maxson, L.D. Hylander, Journal of Cleaner Production 14(3-4), 436 (2006)

49. J. Nriagu, C. Becker, The Science of The Total Environment 304(1-3), 3 (2003)

50. D.M. Pyle, T.A. Mather, Atmospheric Environment 37(36), 5115 (2003)

51. M.S. Gustin, S.E. Lindberg, K. Austin, M. Coolbaugh, A. Vette, H. Zhang, The Science of The Total Environment 259(1-3), 61 (2000)

52. H.R. Friedli, L.F. Radke, J.Y. Lu, C.M. Banic, W.R. Leaitch, J.I. MacPherson, Atmospheric Environment 37(2), 253 (2003)

53. S. Cinnirella, N. Pirrone, Atmospheric Environment 40(38), 7346 (2006)

54. R. Ebinghaus, F. Slemr, C.A.M. Brenninkmeijer, P. van Velthoven, A. Zahn, M. Hermann, D.A. O'Sullivan, D.E. Oram, Geophys. Res. Lett. 34, (2007)

55. C. Wiedinmyer, H. Friedli, Environmental Science \& Technology 41(23), 8092 (2007)

56. AMAP/UNEP, Tech. rep., Arctic Monitoring and Assessment Programme / UNEP Chemicals Branch (2008), http: //www . unep .org/hazardoussubstances /

57. N. Pirrone, S. Cinnirella, X. Feng, R.B. Finkelman, H.R. Friedli, J. Leaner, R. Mason, A.B. Mukherjee, G.B. Stracher, D.G. Streets et al., Atmospheric Chemistry and Physics 10(13), 5951 (2010)

58. N. Pirrone, F. Sprovieri, I.M. Hedgecock, G.A. Trunfio, S. Cinnirella, in Dynamics of Mercury Pollution on Regional and Global Scales:, edited by N. Pirrone, K. Mahafeey (Springer, 2005), chap. 23, pp. 541-579

59. I.M. Hedgecock, N. Pirrone, G.A. Trunfio, F. Sprovieri, Journal Of Geophysical Research Atmospheres 111(D20), D20302 (2006)

60. D. Nacht, M. Gustin, Water, Air, and Soil Pollution 151, 179 (2004)

61. A.W. Rea, S.E. Lindberg, T. Scherbatskoy, G.J. Keeler, Water, Air, \& Soil Pollution 133(1), 49 (2002)

62. M. Lodenius, The Science of The Total Environment 213(1-3), 53 (1998)

63. M. Lodenius, E. Tulisalo, A. Soltanpour-Gargari, The Science of The Total Environment 304(1-3), 169 (2003)

64. J.A. Ericksen, M.S. Gustin, D.E. Schorran, D.W. Johnson, S.E. Lindberg, J.S. Coleman, Atmospheric Environment 37(12), 1613 (2003)

65. J.A. Ericksen, M.S. Gustin, Science of The Total Environment 324(1-3), 271 (2004)

66. S. Cinnirella, N. Pirrone, A. Allegrini, D. Guglietta, Environmental Fluid Mechanics 8(2), 129 (2008)

67. H. Friedli, A. Arellano, S. Cinnirella, N. Pirrone, Environmental Science \& Technology 43(10), 3507 (2009)

68. H.R. Friedli, A.F. Arellano, S. Cinnirella, N. Pirrone, in Mercury Fate and Transport in the Global Atmosphere, edited by N. Pirrone, R. Mason (Springer, New York, 2009), chap. 8, pp. 193-220

69. UNEP, Tech. rep., UNEP, Geneva, Switzerland (2002), http://www.unep.org/ hazardoussubstances/

70. K.H. Telmer, M.M. Veiga, in Mercury Fate and Transport in the Global Atmosphere, edited by N. Pirrone, R. Mason (Springer, New York, 2009), pp. 131-172

71. USGS, Tech. rep., US Geological Survey (2004), minerals.usgs.gov/minerals/pubs/ myb.htm

72. D.G. Streets, J. Hao, Y. Wu, J. Jiang, M. Chan, H. Tian, X. Feng, Atmospheric Environment 39(40), 7789 (2005)

73. D.G. Streets, J. Hao, S. Wang, Y. Wu, in Mercury Fate and Transport in the Global Atmosphere, edited by R. Mason, N. Pirrone (Springer US, 2009), pp. 51-65

74. WCC, Tech. rep., World Chlorine Council (2007)

75. A.B. Mukherjee, R. Zevenhoven, J. Brodersen, L.D. Hylander, P. Bhattacharya, Resources, Conservation and Recycling 42(2), 155 (2004) 
76. A.B. Mukherjee, P. Bhattacharya, A. Sarkar, R. Zevenhoven, in Mercury Fate and Transport in the Global Atmosphere, edited by N. Pirrone, R. Mason (Springer, New York, 2009), chap. 4, pp. 81-112

77. P. Maxson, Tech. rep., Sprl Concorde (2006), ec.europa.eu/environment/chemicals/ mercury

78. G. Stracher, T. Taylor, in Coal Fires Burning around the World: a Global Catastrophe, edited by G. Stracher (Elsevier, 2004), pp. 7-17

79. G. Stracher, GSA Today, International Journal of Coal Geology 17(11), 36 (2007)

80. X. Feng, D. Streets, J. Hao, Y. Wu, G. Li, in Mercury Fate and Transport in the Global Atmosphere, edited by N. Pirrone, R. Mason (Springer, New York, 2009), chap. 3, pp. 67-79

81. N. Pirrone, S. Cinnirella, X. Feng, H.R. Friedli, L. Levine, J. Pacyna, E.G. Pacyna, D.G. Streets, K. Sundseth, Tech. Rep. Chapter B3, LRTAP - Task Force on Hemispheric Transport of Air Pollutants (2010), http://htap.icg.fz-juelich.de/data/ ChapterB3

82. UNEP, Tech. rep., UNEP, Geneva, Swizerland (2006), http://www.unep.org/ hazardoussubstances/

83. E.B. Swain, P.M. Jakus, G. Rice, F. Lupi, P.A. Maxson, J.M. Pacyna, A. Penn, S.J. Spiegel, M.M. Veiga, AMBIO: A Journal of the Human Environment 36(1), 45 (2007)

84. Y. Wu, S. Wang, D.G. Streets, J. Hao, M. Chan, J. Jiang, Environmental Science \& Technology 40(17), 5312 (2006)

85. Y. Wu, D.G. Streets, S.X. Wang, J.M. Hao, Atmospheric Chemistry and Physics 10(6), 2937 (2010)

86. H. Kock, E. Bieber, R. Ebinghaus, T. Spain, B. Thees, Atmospheric Environment 39(39), 7549 (2005)

87. F. Sprovieri, N. Pirrone, K. Gårdfeldt, J. Sommar, Atmospheric Environment 37 (Supplement 1), $63(2003)$

88. I.M. Hedgecock, N. Pirrone, F. Sprovieri, E. Pesenti, Atmospheric Environment 37 (Supplement 1), 41 (2003)

89. I.M. Hedgecock, G.A. Trunfio, N. Pirrone, F. Sprovieri, Atmospheric Environment 39(38), 7217 (2005)

90. R.P. Mason, N.M. Lawson, G.R. Sheu, Deep Sea Research Part II: Topical Studies in Oceanography 48(13), 2829 (2001)

91. F.J.G. Laurier, R.P. Mason, L. Whalin, S. Kato, Journal Of Geophysical Research - Atmospheres 108, (2003)

92. F. Slemr, W. Seiler, G. Schuster, Journal Of Geophysical Research - Atmospheres 86, 1159 (1981)

93. F. Slemr, G. Schuster, W. Seiler, Journal of Atmospheric Chemistry 3(4), 407 (1985)

94. F. Slemr, E. Langer, Nature 355(6359), 434 (1992)

95. F. Slemr, W. Junkermann, R.W.H. Schmidt, R. Sladkovic, Geophysical Research Letters 22, (1995)

96. C.H. Lamborg, K.R. Rolfhus, W.F. Fitzgerald, G. Kim, Deep Sea Research Part II: Topical Studies in Oceanography 46(5), 957 (1999)

97. P.G.L. Baker, E.G. Brunke, F. Slemr, A.M. Crouch, Atmospheric Environment 36(14), 2459 (2002)

98. F. Laurier, R. Mason, Journal Of Geophysical Research - Atmospheres 112, (2007)

99. R.P. Mason, K.A. Sullivan, Deep Sea Research Part II: Topical Studies in Oceanography 46(5), 937 (1999)

100. R. Mason, W. Fitzgerald, Water, Air, \& Soil Pollution 56(1), 779 (1991)

101. R. Mason, W. Fitzgerald, Deep Sea Research Part I: Oceanographic Research Papers 40, 1897 (1993)

102. R. Mason, J. O'Donnell, W. Fitzgerald, in Pollution Integration and Synthesis (Lewis Publishers, 1994), pp. 83-97

103. R. Wanninkhof, Journal Of Geophysical Research - Atmospheres 97, (1992) 
104. J. Sommar, I. Wängberg, T. Berg, K. Gårdfeldt, J. Munthe, A. Richter, A. Urba, F. Wittrock, W. Schroeder, Atmospheric Chemistry and Physics 7(1), 151 (2007)

105. V. St Louis, H. Hintelmann, J.A. Graydon, J.L. Kirk, J. Barker, B. Dimock, M.J. Sharp, I. Lehnherr, Environmental Science \& Technology 41(18), 6433 (2007)

106. R. Wanninkhof, W.R. McGillis, Geophysical Research Letters 26, 1889 (1999)

107. M. Andersson, J. Sommar, K. Gårdfeldt, O. Lindqvist, Marine Chemistry 110(3-4), 190 (2008)

108. J. Sommar, M.E. Andersson, H.W. Jacobi, Atmospheric Chemistry and Physics 10(11), 5031 (2010)

109. F. Sprovieri, N. Pirrone, Environmental Fluid Mechanics 8(2), 117 (2008)

110. F. Sprovieri, N. Pirrone, R. Ebinghaus, H. Kock, A. Dommergue, Atmospheric Chemistry and Physics 10(17), 8245 (2010)

111. K. Gårdfeldt, J. Sommar, R. Ferrara, C. Ceccarini, E. Lanzillotta, J. Munthe, I. Wängberg, O. Lindqvist, N. Pirrone, F. Sprovieri et al., Atmospheric Environment 37(Supplement 1), 73 (2003)

112. M. Horvat, J. Kotnik, M. Logar, V. Fajon, T. Zvonarić, N. Pirrone, Atmospheric Environment 37, 93 (2003)

113. J. Kotnik, M. Horvat, E. Tessier, N. Ogrinc, M. Monperrus, D. Amouroux, V. Fajon, D. Gibicar, S. Zizek, F. Sprovieri et al., Marine Chemistry 107(1), 13 (2007)

114. D. Cossa, J.M. Martin, K. Takayanagi, J. Sanjuan, Deep Sea Research Part II: Topical Studies in Oceanography 44, 721 (1997)

115. M. Coquery, D. Cossa, J.M. Martin, Water, Air, \& Soil Pollution 80(1), 653 (1995)

116. W. Baeyens, M. Leermakers, Marine Chemistry 60(3-4), 257 (1998)

117. I. Wängberg, S. Schmolke, P. Schager, J. Munthe, R. Ebinghaus, Å. Iverfeldt, Atmospheric Environment 35(32), 5477 (2001)

118. J. Kuss, B. Schneider, Environmental Science \& Technology 41(23), 8018 (2007)

119. A. Weiss, J. Kuss, G. Peters, B. Schneider, Journal of Marine Systems 66(1-4), 130 (2007)

120. L. Poissant, M. Pilote, C. Beauvais, P. Constant, H.H. Zhang, Atmospheric Environment 39(7), $1275(2005)$

121. Y.J. Han, T.M. Holsen, S.O. Lai, P.K. Hopke, S.M. Yi, W. Liu, J. Pagano, L. Falanga, M. Milligan, C. Andolina, Atmospheric Environment 38(37), 6431 (2004)

122. N. Hachiya, Y. Takizawa, S. Hisamatsu, T. Abe, Y. Abe, Y. Motohashi, Environmental Health and Preventive Medicine 2(4), 183 (1998)

123. P. Higueras, R. Oyarzun, J. Lillo, J. Oyarzún, H. Maturana, Atmospheric Environment 39(39), 7587 (2005)

124. A.H. Fostier, P.A. Michelazzo, Journal of the Brazilian Chemical Society 17, 886 (2006)

125. D. Amouroux, J.C. Wasserman, E. Tessier, O.F.X. Donard, Environmental Science \& Technology 33(17), 3044 (1999)

126. D. de la Rosa, T. Volke-Sepulveda, G. Solarzano, C. Green, R. Tordon, S. Beauchamp, Atmospheric Environment 38(29), 4839 (2004)

127. H. Nguyen, K.H. Kim, M.Y. Kim, S. Hong, Y.H. Youn, Z.H. Shon, J. Lee, Water, Air, \& Soil Pollution 185(1), 149 (2007)

128. X. Fu, X. Feng, W. Zhu, S. Wang, J. Lu, Atmospheric Environment 42(5), 970 (2008)

129. Q. Wan, X. Feng, J. Lu, W. Zheng, X. Song, S. Han, H. Xu, Environmental Research 109(3), 201 (2009)

130. X. Fu, X. Feng, S. Wang, S. Rothenberg, L. Shang, Z. Li, G. Qiu, Science of The Total Environment 407(7), 2306 (2009)

131. X.W. Fu, X. Feng, Z.Q. Dong, R.S. Yin, J.X. Wang, Z.R. Yang, H. Zhang, Atmospheric Chemistry and Physics 10(5), 2425 (2010)

132. X. Feng, L. Shang, S. Wang, S. Tang, W. Zheng, Journal Of Geophysical Research - Atmospheres 109, (2004)

133. X. Feng, S. Tang, L. Shang, H. Yan, J. Sommar, O. Lindqvist, The Science of The Total Environment 304(1-3), 61 (2003)

134. X. Feng, G. Qiu, Science of The Total Environment 400(1-3), 227 (2008) 
135. C. Banic, S. Beauchamp, R. Tordon, W. Schroeder, A. Steffen, K. Anlauf, H. Wong, Journal Of Geophysical Research - Atmospheres 108, 4264 (2003)

136. R. Ebinghaus, F. Slemr, Atmospheric Environment 34(6), 895 (2000)

137. H.R. Friedli, L.F. Radke, R. Prescott, P. Li, J.H. Woo, G.R. Carmichael, Journal Of Geophysical Research - Atmospheres 109, (2004)

138. P. Weiss-Penzias, D. Jaffe, P. Swartzendruber, W. Hafner, D. Chand, E. Prestbo, Atmospheric Environment 41(21), 4366 (2007)

139. D. Jaffe, H. Price, D. Parrish, A. Goldstein, J. Harris, Geophys. Res. Lett. 30, (2003)

140. M.S. Landis, M.M. Lynam, R.K. Stevens, The monitoring and modelling of Hg species in support of local, regional and global modelling (Springer, 2005), chap. 7, pp. 123-151

141. F. Slemr, E.G. Brunke, R. Ebinghaus, C. Temme, J. Munthe, I. Wängberg, W. Schroeder, A. Steffen, T. Berg, Geophys. Res. Lett. 30, (2003)

142. G. Sheu, C. Lee, N. Lin, AGU Fall Meeting Abstracts pp. C1350+ (2007)

143. P.C. Swartzendruber, D.A. Jaffe, E.M. Prestbo, P. Weiss-Penzias, N.E. Selin, R. Park, D.J. Jacob, S. Strode, L. Jaeglé, Journal Of Geophysical Research - Atmospheres 111, (2006)

144. F. Sprovieri, N. Pirrone, I.M. Hedgecock, M.S. Landis, R.K. Stevens, Journal Of Geophysical Research - Atmospheres 107(D23), 4722 (2002)

145. F. Sprovieri, N. Pirrone, M. Landis, R. Stevens, Atmospheric Environment 39(39), 7646 (2005)

146. F. Sprovieri, N. Pirrone, M.S. Landis, R.K. Stevens, Environmental Science \& Technology 39(23), $9156(2005)$

147. C. Temme, J.W. Einax, R. Ebinghaus, W.H. Schroeder, Environmental Science \& Technology 37(1), 22 (2003)

148. A. Steffen, T. Douglas, M. Amyot, P. Ariya, K. Aspmo, T. Berg, J. Bottenheim, S. Brooks, F. Cobbett, A. Dastoor et al., Atmospheric Chemistry and Physics 8(6), 1445 (2008)

149. A. Dommergue, F. Sprovieri, N. Pirrone, R. Ebinghaus, S. Brooks, J. Courteaud, C.P. Ferrari, Atmospheric Chemistry and Physics 10(7), 3309 (2010)

150. W.H. Schroeder, J. Munthe, Atmospheric Environment 32(5), 809 (1998)

151. T. Berg, S. Sekkesæter, E. Steinnes, A.K. Valdal, G. Wibetoe, The Science of The Total Environment 304(1-3), 43 (2003)

152. K. Aspmo, P.A. Gauchard, A. Steffen, C. Temme, T. Berg, E. Bahlmann, C. Banic, A. Dommergue, R. Ebinghaus, C. Ferrari et al., Atmospheric Environment 39(39), 7607 (2005)

153. S.E. Lindberg, S. Brooks, C.J. Lin, K. Scott, T. Meyers, L. Chambers, M. Landis, R. Stevens, Water, Air, \& Soil Pollution: Focus 1(5), 295 (2001)

154. H. Skov, J.H. Christensen, M.E. Goodsite, N.Z. Heidam, B. Jensen, P. Wåhlin, G. Geernaert, Environmental Science \& Technology 38(8), 2373 (2004)

155. L. Poissant, M. Pilote, J. Phys. IV France 107, 1079 (2003)

156. A. Steffen, W. Schroeder, R. Macdonald, L. Poissant, A. Konoplev, Science of The Total Environment 342(1-3), 185 (2005)

157. R. Ebinghaus, H.H. Kock, C. Temme, J.W. Einax, A.G. Lowe, A. Richter, J.P. Burrows, W.H. Schroeder, Environmental Science \& Technology 36(6), 1238 (2002)

158. R. Dietz, P.M. Outridge, K.A. Hobson, Science of The Total Environment 407(24), 6120 (2009)

159. R. Bargagli, Science of The Total Environment 400(1-3), 212 (2008)

160. R. Bargagli, C. Agnorelli, F. Borghini, F. Monaci, Environmental Science \& Technology 39(21), 8150 (2005)

161. S.J. de Mora, J.E. Patterson, D.M. Bibby, Antarctic Science 5(03), 323 (1993)

162. J.G. Calvert, S.E. Lindberg, Atmospheric Environment 39(18), 3355 (2005)

163. P.A. Ariya, K. Peterson, G. Snider, M. Amyot, in Mercury Fate and Transport in the Global Atmosphere: Emissions, Measurements and Models, edited by N. Pirrone, R.P. Mason (Springer, 2009), chap. 15, pp. 459-501

164. P.A. Ariya, A. Khalizov, A. Gidas, The Journal of Physical Chemistry A 106(32), 7310 (2002)

165. M.E. Goodsite, J.M.C. Plane, H. Skov, Environmental Science \& Technology 38(6), 1772 (2004)

166. I.M. Hedgecock, N. Pirrone, F. Sprovieri, Environmental Chemistry 5(2), 131 (2008)

167. C.D. Holmes, D.J. Jacob, X. Yang, Geophys. Res. Lett. 33, L20808 (2006)

168. C.D. Holmes, D.J. Jacob, R.P. Mason, D.A. Jaffe, Atmospheric Environment 43(14), 2278 (2009) 
169. F. Sprovieri, I.M. Hedgecock, N. Pirrone, Atmospheric Chemistry and Physics 10(8), 3985 (2010)

170. P. Pongprueksa, C.J. Lin, S.E. Lindberg, C. Jang, T. Braverman, O.R.B. Jr., T.C. Ho, H.W. Chu, Atmospheric Environment 42(8), 1828 (2008)

171. K. Vijayaraghavan, P. Karamchandani, C. Seigneur, R. Balmori, S.Y. Chen, Journal Of Geophysical Research - Atmospheres 113(D24), D24305 (2008)

172. K. Gårdfeldt, M. Jonsson, The Journal of Physical Chemistry A 107(22), 4478 (2003)

173. A. Ryaboshapko, O.R. Bullock, Jr., J. Christensen, M. Cohen, A. Dastoor, I. Ilyin, G. Petersen, D. Syrakov, R.S. Artz et al., Science of The Total Environment 376(1-3), 228 (2007)

174. A. Ryaboshapko, O.R. Bullock, Jr., J. Christensen, M. Cohen, A. Dastoor, I. Ilyin, G. Petersen, D. Syrakov, O. Travnikov et al., Science of The Total Environment 377(2-3), 319 (2007)

175. C.J. Lin, P. Pongprueksa, S.E. Lindberg, S.O. Pehkonen, D. Byun, C. Jang, Atmospheric Environment 40(16), 2911 (2006)

176. C.J. Lin, P. Pongprueksa, O.R.B. Jr., S.E. Lindberg, S.O. Pehkonen, C. Jang, T. Braverman, T.C. Ho, Atmospheric Environment 41(31), 6544 (2007)

177. N. Pirrone, R. Mason, eds., Mercury Fate and Transport in the Global Atmosphere (Springer, 2009)

178. R. von Glasow, Proceedings of the National Academy of Sciences 107(15), 6594 (2010)

179. C.D. Holmes, D.J. Jacob, E.S. Corbitt, J. Mao, X. Yang, R. Talbot, F. Slemr, Atmospheric Chemistry and Physics Discussions 10(8), 19845 (2010)

180. T. Bergan, L. Gallardo, H. Rodhe, Atmospheric Environment 33(10), 1575 (1999)

181. C. Seigneur, K. Vijayaraghavan, K. Lohman, P. Karamchandani, C. Scott, Environmental Science \& Technology 38(2), 555 (2004)

182. N.E. Selin, D.J. Jacob, R.J. Park, R.M. Yantosca, S. Strode, L. Jaeglé, D. Jaffe, Journal Of Geophysical Research - Atmospheres 112(D2), D02308 (2007)

183. F. Sprovieri, N. Pirrone, Journal of Aerosol Science 31(Supplement 1), 757 (2000)

184. S. Brooks, R. Arimoto, S. Lindberg, G. Southworth, Atmospheric Environment 42(12), 2877 (2008)

185. R. Arimoto, C. Schloesslin, D. Davis, A. Hogan, P. Grube, W. Fitzgerald, C. Lamborg, Atmospheric Environment 38(32), 5485 (2004)

186. S. Brooks, S. Lindberg, G. Southworth, R. Arimoto, Atmospheric Environment 42(12), 2885 (2008) 